\title{
Diallel Analysis for Area, Chlorophyll and Temperature of Flag Leaf in Bread Wheat under Well Watered and Drought Stress Conditions
}

\author{
Naheif E. Mohamed ${ }^{1}$, Ismail M. Bedawy ${ }^{1} \&$ Yasser A. M. Hefny ${ }^{1}$ \\ ${ }^{1}$ Agronomy Department, Faculty of Agriculture, Sohag University, Sohag, Egypt \\ Correspondence: Naheif E. Mohamed, Agronomy Department, Faculty of Agriculture, Sohag University, Sohag, \\ Egypt. E-mail: naheif1974@gmail.com
}

Received: July 14, 2021

Accepted: August 15, $2021 \quad$ Online Published: September 15, 2021

doi:10.5539/jas.v13n10p45

URL: https://doi.org/10.5539/jas.v13n10p45

\begin{abstract}
To study genetic analysis of some physiological traits of drought stress in wheat using diallel techniques, an experiment was performed on ten bread wheat genotypes as parents and their $45 \mathrm{~F}_{1}$ hybrids in a randomized complete block design with three replicates under well-watered and drought stress conditions at the Research Farm of Faculty of Agriculture, Sohag University, Egypt during season of 2018/19. The results showed significant differences between the genotypes $(\mathrm{G})$, Parents $(\mathrm{P}), \mathrm{F}_{1}$ crosses, $\mathrm{P} v \mathrm{~s} . \mathrm{F}_{1}$, GCA and SCA under well-watered and drought stress in the flag leaf area (FLA), flag leaf chlorophyll content (FLCC) and flag leaf temperature (FLT), except FLCC for $\mathrm{F}_{1}$ crosses exhibited insignificant differences. The significant differences were found in the interaction of SCA $\times$ Env., in all studied traits and GCA $\times$ Env., for FLT., indicating the involvement of both additive and dominance gene action in their inheritance. The most desirable heterotic effects were considered as the largest positive heterosis estimates for FLA and FLCC, and the lowest negative for FLT. The parent numbers $\mathrm{P}_{9}, \mathrm{P}_{8}$ and $\mathrm{P}_{3}$ were the best general combiner for FLA under normal irrigation and drought stress. While the parents $\mathrm{P}_{2}, \mathrm{P}_{7}$ and $\mathrm{P}_{9}$ were the best general combiner for FLCC, under normal irrigation and $\left(\mathrm{P}_{1}\right.$, $\mathrm{P}_{2}$ and $\mathrm{P}_{3}$ ) under drought stress. Therefor the parents $\mathrm{P}_{1}, \mathrm{P}_{4}$ and $\mathrm{P}_{5}$ were the best general combiner for FLT under normal irrigation, also the $\mathrm{P}_{3}, \mathrm{P}_{4}$ and $\mathrm{P}_{5}$ were the best general combiner for FLT under drought stress conditions. Under normal irrigation and drought stress conditions as well as the combined data, the additive genetic components of variation $\left(\mathrm{V}_{\mathrm{A}}\right)$ in $\mathrm{F}_{1}$ 's was much greater than dominance component $\left(\mathrm{V}_{\mathrm{D}}\right)$, as expressed by the $\left(\mathrm{V}_{\mathrm{A}} / \mathrm{V}_{\mathrm{D}}\right)$ ratio which was more than unity for the FLA, and FLT under normal irrigation and their combined. This indicates that the additive gene effects in $F_{1}$ crosses are more important than dominance and plays the major role in the inheritance of these studied traits.
\end{abstract}

Keywords: Diallel analysis, Drought stress, GCA, SCA, physiological

\section{Introduction}

Wheat is the most important cereal crops in terms of area and production. Its importance is derived from many properties and uses of its grain, which make it a staple food for more than one third of the world's population. Wheat supplies about 20 percent of the food calories for the world's people and is a national staple in many countries (Braun et al., 2010). Wheat is the most important and widely adapted food cereal in Egypt. Wheat production per unit area is 6.38 ton/ha with the actual local production is about 9.00 million tons (http://www.fao.org/faostat) (FAO, 2019). However, still there is a big gap between the consumption and local production (48\%). Another challenge facing Egypt is the growth of its population that is expected to reach 170 million by 2050 (Boko et al., 2007). Flag leaf photosynthesis rate depressed dramatically under abiotic stress at anthesis stage, cell membrane peroxidation enhanced due to enhancement of $\mathrm{O}_{2}$ production and activities of antioxiditave enzymes were reduced (Wang et al., 2011). Dehydration avoidance in a wheat spike in late drought or heat stress induced senescence related to the flag leaf (Tambussi et al., 2007; Vicente et al., 2018). Gámez et al. (2020) reported that the higher ear gross photosynthesis, together with leaf photosynthesis enhancement, explained the increase in plant biomass and yield under the contribution of flag leaf to grain filling is important not only under good agronomic conditions, but also under high $\left(\mathrm{CO}_{2}\right)$. Carbon dioxide fixed after anthesis by the ear in wheat is ranged from 17 up to $30 \%$ of the grain weight, whereas in the absence of severe drought stress of wheat plant largely succeeds in grain development within the ear and the flag leaf area correlation with yield not by physiological activity but also by the correlation in development of large flag leaves and large ears (Thorne, 
1965). Under favorable conditions, flag leaf is an important contribution to grain yield, 1000-kernel weight, and grain number, compared to penultimate and antepenultimate leaves. Flag leaf can contribute up to 48 and $22 \%$ for grain yield and number of grains (El Wazziki, 2015). The importance of flag leaf might be due to its longer green period, short distance to the spike, and direct implication in solar radiation interception (Birsin, 2005; Khaliq et al., 2004). Using drought tolerant wheat cultivars that consume less water and can tolerate soil water deficit could solve this problem. Producing new alleles and new allelic combinations that may have provided more ground for adaptation and selection (Contreras-Moreira et al., 2019). Diallel crosses represent the best strategy for determining the general (GCA) and specific (SCA) combining abilities between putative parents as subsequently, the choice of breeding methods (Chukwu et al., 2016; Samah, 2019). The current investigation aimed to: (1) Study the effect of drought stress at anthesis stage on some physiological traits for $\mathrm{F}_{1}$ crosses and their parents. (2) Estimation of the general and specific combining ability effects and the genetic behavior of the parents and their crosses related to physiological traits.

\section{Materials and Methods}

\subsection{Plant Materials and Layout}

The current investigation was carried out during winter season of 2018/19 at Research Farm, Faculty of Agriculture, Sohag University, Egypt. Ten genetically diverse of bread wheat (Triticum aestivum L.) genotypes (Table 1) included of three Egyptian cultivars (Giza-168, Sids-12 and Misr-1) and seven accessions, their seeds were imported in 2010 from Nordic Genetic Resource Center (Nord Gen) then, after adapted under Sohag conditions. $F_{1}$ seeds of each 45 crosses as well as their parents were sown in the field of two experiments in a randomized complete block design (RCBD) with three replications. Each plot consisted of 3 rows, $3 \mathrm{~m}$ long and $20 \mathrm{~cm}$ wide; with seed spaced $10 \mathrm{~cm}$ a part (plot size $=1.8 \mathrm{~m}^{2}$ ). The first experiment was subjected to normal irrigation conditions and the second one exposed to drought stress conditions at anthesis stage (withholding water from anthesis to maturity).

\subsection{Measurements}

Three physiological traits were recorded for $45 \mathrm{~F}_{1}$ crosses and their parents as following: (1) Flag leaf Chlorophyll content (FLCC): was recorded in the middle of 20 flag leaves using SPAD 502. (2) Flag leaf area was measured by (maximum length $\times$ maximum width $\times 0.75$ ) of 20 flag leaves according to (Blum, 1983). (3) Flag leaf temperature: it was measured by Infrared thermometer at mid-day in 20 flag leaves.

Table 1. The 10 parents including Giza168, Sids12, Misr1 and 7 imported genotypes

\begin{tabular}{lllllllllll}
\hline Parents & P1 & P2 & P3 & P4 & P5 & P6 & P7 & P8 & P9 & P10 \\
\hline Code & NGB6404 & NGB6406 & NGB10893 & NGB11099 & NGB9955 & NGB6681 & NGB8950 & Giza 168 & Sids 12 & Misr 1 \\
Country & unknown & unknown & Denmark & Denmark & Sweden & Sweden & unknown & Egypt & Egypt & Egypt \\
\hline
\end{tabular}

\subsection{Biometrical and genetic analyses}

Data of the $\mathrm{F}_{1}$ diallel ( $45 \mathrm{~F}_{1} \mathrm{~S}$ and 10 parents) recorded under normal irrigation as well as for drought stress were subjected to the single analysis of variance and combine analysis of two environments in randomized complete blocks design using SAS software (SAS ver. 9.2, SAS Institute 2008) acceding to K. A. Gomez and A. A. Gomez (1984). Analyses of Genetic Designs were performed in R. Version 3.0 (2018-06-20). Genotypes degrees of freedom were partitioned into parents, crosses, and parents $v s$. crosses. The $\mathrm{F}_{1}$ degrees of freedom were partitioned into general combining ability (GCA) and specific combining ability (SCA) according to Method-2 Model-I of Griffing (1956), furthermore the interaction degrees of freedom for Genotypes $\times$ Environment, were partitioned into GCA $\times$ Environment and SCA $\times$ Environment according to Method-2 Model-I of Griffing, (1956). The least significant differences (LSD) between means for combined analysis were estimated according to Snedecor and Cochran (1989).

\subsubsection{Estimating the Variance Components in $\mathrm{F}_{1}$ Generation}

$\mathrm{V}_{\text {gca }}=\left(\mathrm{MS}_{\mathrm{gca}}-\mathrm{MS}_{\mathrm{e}}\right) /(\mathrm{P}+2) ; \mathrm{V}_{\mathrm{sca}}=\left(\mathrm{MS}_{\mathrm{sca}}-\mathrm{MS}_{\mathrm{e}}\right) ; \mathrm{V}_{\mathrm{p}}=2 \mathrm{~V}_{\mathrm{gca}}+\mathrm{V}_{\text {sca }}+\mathrm{V}_{\mathrm{E}} ; \mathrm{V}_{\mathrm{G}}=2 \mathrm{~V}_{\mathrm{gca}}+\mathrm{V}_{\text {sca }} ; \mathrm{V}_{\mathrm{A}}=2 \mathrm{~V}_{\text {gca }} ; \mathrm{V}_{\mathrm{D}}=$ $\mathrm{V}_{\mathrm{gca}}-\mathrm{V}_{\mathrm{A}}$, where, $\mathrm{MS}_{\mathrm{gca}}=$ mean squares of general combining ability, $\mathrm{MS}_{\mathrm{sca}}=$ nean square of specific combining ability, $\mathrm{V}_{\text {gca }}=\mathrm{GCA}$ variance, $\mathrm{V}_{\text {sca }}=\mathrm{SCA}$ variance, $\mathrm{V}_{\mathrm{P}}=$ phenotypic variance, $\mathrm{V}_{\mathrm{G}}=$ genotypic variance, $\mathrm{V}_{\mathrm{A}}=$ additive variance, $\mathrm{V}_{\mathrm{D}}=$ dominance variance. 


\subsubsection{Average Degree of Dominance Calculation}

Average degree of dominance $[\mathrm{a}]$ was calculated by the following equation: $[\mathrm{a}]=\left[2 \mathrm{~V}_{\mathrm{D}} / \mathrm{V}_{\mathrm{A}}\right]^{1 / 2}$. The estimates of the average degree of dominance [a] were used to indicate the type of dominance, as follows: [a] $=0$ indicates no dominance, $[\mathrm{a}]<1$ indicates partial dominance, $[\mathrm{a}]=1$ indicates complete dominance and $[\mathrm{a}]>1$ indicates over dominance.

\subsubsection{Estimating Heritability and Genetic Advance From Selection}

Heritability in the broad $\left(\mathrm{H}_{\mathrm{b}}\right)$ and narrow $\left(\mathrm{H}_{\mathrm{n}}\right)$ sense in $\mathrm{F}_{1}$ were estimated from the following formulae: $\mathrm{H}_{\mathrm{b}}=$ $\left(\mathrm{V}_{\mathrm{G}} / \mathrm{V}_{\mathrm{P}}\right) \times 100$, and $\mathrm{H}_{\mathrm{n}}=\left(\mathrm{V}_{\mathrm{A}} / \mathrm{V}_{\mathrm{P}}\right) \times 100$. The expected genetic advance from selection was calculated as follows: $\mathrm{GA}=\mathrm{K} \times \mathrm{Hb} \times\left(\mathrm{V}_{\mathrm{P}}\right)^{1 / 2}$, where, $\mathrm{k}$ is the intensity of selection $(\mathrm{k}=2.06$ at $5 \%$ selection intensity). Genetic advance over mean $(\mathrm{GAM})=(\mathrm{GA} / \bar{X}) \times 100$.

\subsubsection{Heterosis Estimation}

Percentages of $F_{1}$ relative to the mid parent (heterosis) for studied traits of the $F_{1}$ diallel were calculated as follows: Heterosis $(\%)=\left(F_{1}-M P\right) / M P$. Percentages of $F_{1}$ relative to the best parent (heterobeltiosis) for studied traits of the $\mathrm{F}_{1}$ diallel were calculated as follows: Heterosis $(\%)=\left(\mathrm{F}_{1}-\mathrm{BP}\right) / \mathrm{BP}$, where, $\mathrm{F}_{1}=$ mean of the $\mathrm{F}_{1}$ cross, $\mathrm{MP}=$ mid parents of the $\mathrm{F}_{1}$ cross, $\mathrm{BP}=$ mean of the better parent.

\section{Results and Discussions}

\subsection{Analysis of Variance of Ten Parents and Their Crosses}

The significant or highly significant differences were found among the 10 parents for studied traits traits under normal irrigation, drought stress and overall, two environments, the flag leaf area (FLA), flag leaf chlorophyll content (FLCC) and flag leaf temperature (FLT) under normal irrigation and drought stress showed highly significant differences between these parents (Table 2). These results are harmony with those obtained by Esmail et al. (2016), and Samah (2019), they revealed that highly significant differences among the genotypes for all characters indicating the presence of considerable variability among the bread wheat lines. Gautam et al. (2016), and Sharma et al. (2018) revealed that physiological traits like canopy temperature and Chlorophyll (Chl) fluorescence could be used as stress markers in field conditions to screen stress tolerant and sensitive wheat genotypes under adverse conditions. Similarity, highly significant differences were found among the $45 \mathrm{~F}_{1}$ crosses under normal irrigation, drought stress and overall, two environments for all studied traits, except the chlorophyll content of flag leaf showed insignificant differences among the $F_{1}$ crosses under drought stress and over two environments (Table 2). These results are similar with those obtained by Masood et al. (2005), Al-Otayk (2010), Mohammadi et al. (2012), Esmail et al. (2016), Moharam et al. (2017), and Sharma and Uddin (2020). Furthermore, highly significant differences were found in the physiological traits except the FLT under normal irrigation only were insignificant differences and overall, two environments (Table 2). The general combining ability (GCA) was highly significant differences in all studied traits under both of normal irrigation, drought stress and overall environments. Specific combining ability (SCA) were exhibited highly significant differences in all studied traits under normal irrigation, drought stress and overall tow environments, except the FLT under overall two environments were insignificant. These finding are very similar with those obtained by Ahmad (2010) found that the mean squares of the genotypes (six parents and their $15 \mathrm{~F}_{1}$ crosses), GCA and SCA were highly significant for days to $50 \%$ blooming. These results indicated that both additive and non-additive gene effects played important roles in the inheritance of flag leaf area (FLA), flag leaf chlorophyll content (FLCC) and flag leaf temperature (FLT) traits under normal irrigation and drought stress conditions. the interaction of GCA $\times$ Env., was highly significant differences in the flag leaf temperature (FLT) and insignificant differences in flag leaf area (FLA) and flag leaf chlorophyll content (FLCC). Golparvar (2013) found that mean square of general combining ability was significant also for flag leaf area (FLA) and mean square of specific combining ability was significant also for the same trait of bread wheat cultivars under drought stress condition. These results due to the insignificant differences $F_{1}$ and Parents under normal irrigation, and insignificant differences between $F_{1}$ crosses in FLCC under drought stress and overall, two environments. These results confirmed by Said (2014), Jatoi et al. (2014), and Sharma and Uddin (2020). In addition, the interaction of SCA $\times$ Env., had highly significant differences in all studied traits, these results due to the significant differences of Gen. $\times$ Env., in all studied traits.

\subsection{Mean Performance of the Parents}

Data presented in Table 3 revealed that significant differences were found between the parents in all studied traits under normal irrigation and drought stress conditions. The parents $\mathrm{P}_{9}, \mathrm{P}_{8}$ and $\mathrm{P}_{3}$ were larger flag leaf area (32.59, 31.14 and $\left.27.57 \mathrm{~cm}^{2}\right)$ and $\left(31.34,20.04\right.$ and $\left.20.37 \mathrm{~cm}^{2}\right)$ under normal irrigation and drought stress, respectively 
indicating that these parents are a higher photosynthetic rate in the end of growth season under normal irrigation and drought tress.

Table 2. Analysis of variance of physiological traits for 10 parents and their $F_{1}$ crosses under normal irrigation, drought stress conditions and over two environments

\begin{tabular}{|c|c|c|c|c|c|c|c|c|c|c|c|c|}
\hline \multicolumn{8}{|c|}{ Normal irrigation and drought stress } & \multicolumn{5}{|c|}{ Combined analysis } \\
\hline \multirow{2}{*}{ S.O.V } & \multirow{2}{*}{ DF } & \multicolumn{2}{|c|}{ FLA } & \multicolumn{2}{|c|}{ FLCC } & \multicolumn{2}{|c|}{ FLT } & \multirow{2}{*}{ S.O.V } & \multirow{2}{*}{ DF } & \multirow{2}{*}{ FLA } & \multirow{2}{*}{ FLCC } & \multirow{2}{*}{ FLT } \\
\hline & & WW & DS & WW & DS & WW & DS & & & & & \\
\hline Rep & 2 & 2.56 & 12.35 & 3.59 & 5.75 & 0.01 & 12.35 & Env. & 1 & $758.1 * *$ & $1521.4^{* *}$ & $656.6^{* *}$ \\
\hline Gen. & 54 & $51.61 * *$ & $46.98 * *$ & $31.89^{* * *}$ & $36.10^{* *}$ & $7.70 * *$ & $46.98 * *$ & Rep (Env) & 4 & 7.46 & 4.67 & 0.12 \\
\hline parents & 9 & $62.58 * *$ & $58.03 * *$ & $37.38 * *$ & $32.54 * *$ & $6.71 *$ & $58.03 * *$ & Gen. & 54 & $88.06^{* *}$ & $52.72 * *$ & $8.77 * *$ \\
\hline F1 Crosses & 44 & $48.70 * *$ & $37.69 * *$ & $22.18^{* *}$ & $16.27 \mathrm{~ns}$ & $8.06^{* *}$ & $37.69 * *$ & Parents & 9 & $111.3 * *$ & $46.79 * *$ & $5.58 * *$ \\
\hline P. vs. $F_{1}$ & 1 & $80.78 * *$ & $356.33^{* *}$ & $409.5 * *$ & $940.4 * *$ & 0.36 & $356.3^{*}$ & $\mathbf{F}_{1}$ & 44 & $76.50 * *$ & $25.68 \mathrm{~ns}$ & $9.50 * *$ \\
\hline Error & 108 & 4.76 & 4.58 & 8.50 & 11.44 & 1.13 & 4.58 & P. vs. $F_{1}$ & 1 & $388.2 * *$ & $1295.5^{* *}$ & $5.75 \mathrm{~ns}$ \\
\hline GCA & 9 & $232.19 * *$ & $171.66^{* *}$ & $39.33 * *$ & $30.35 * *$ & $25.06 * *$ & $171.6^{* *}$ & Env $\times$ Gen & 54 & $10.52 * *$ & $15.27^{*}$ & $4.34 * *$ \\
\hline \multirow[t]{5}{*}{ SCA } & 45 & $15.49 * *$ & $22.04 * *$ & $30.40 * *$ & $37.25^{* *}$ & $4.22 * *$ & $22.04 * *$ & Error & 216 & 4.67 & 9.97 & 1.20 \\
\hline & & & & & & & & GCA & 9 & $397.1 * *$ & $57.67 * *$ & $29.40^{*}$ \\
\hline & & & & & & & & SCA & 45 & $26.24 * *$ & $51.72 * *$ & $4.65 \mathrm{~ns}$ \\
\hline & & & & & & & & $\mathbf{E n v} \times \mathbf{G C A}$ & 9 & $6.65 \mathrm{~ns}$ & $12.01 \mathrm{~ns}$ & $10.22 * *$ \\
\hline & & & & & & & & Env $\times$ SCA & 45 & $11.29 * *$ & $15.92 *$ & $3.16 * *$ \\
\hline
\end{tabular}

Note. $\mathrm{WW}=$ Normal irrigation, $\mathrm{DS}=$ Drought stress, $\mathrm{DH}=$ Days to $50 \%$ heading, $\mathrm{DA}=$ Days to $50 \%$ anthesis, $\mathrm{DM}=$ Days to $50 \%$ maturity, $*=$ significant differences at $5 \%$ levels, $* *=$ high significant differences at $1 \%$ levels.

The parents $\mathrm{P}_{10}, \mathrm{P}_{9}$ and $\mathrm{P}_{2}$ were the highest in the flag leaf chlorophyll content $(50.71,51.01$ and 46.43 SPAD) under normal irrigation, while the higher parents in FLCC were $\mathrm{P}_{7}, \mathrm{P}_{3}$ and $\mathrm{P}_{2}(39.59,39.92$ and 40.52 SPAD) under drought stress condition. Furthermore, these parents were differed significantly in the flag leaf temperature. The lowest flag leaf temperature (FLT) was found in $\mathrm{P}_{1}, \mathrm{P}_{2}$ and $\mathrm{P}_{3}\left(21.40,23.36\right.$ and $\left.23.49{ }^{\circ} \mathrm{C}\right)$ under normal irrigation, while the $\mathrm{P}_{3}, \mathrm{P}_{4}$ and $\mathrm{P}_{9}$ were the lowest FLT $\left(28.01,28.55\right.$ and $27.97{ }^{\circ} \mathrm{C}$ ) under drought stress conditions. Drought tolerant genotypes had canopy temperature depression (CTD) as compared to intermediate and susceptible genotypes (Hasheminasab et al., 2012).

Table 3. Performance reduction percentage of the parents for physiological traits under normal irrigation, drought stress conditions

\begin{tabular}{|c|c|c|c|c|c|c|c|c|c|}
\hline \multirow{2}{*}{ Parent } & \multicolumn{3}{|c|}{ Flag leaf area } & \multicolumn{3}{|c|}{ Flag leaf chl. } & \multicolumn{3}{|c|}{ Flag leaf temp. } \\
\hline & $\mathbf{W W}$ & DS & Red. \% & $\mathbf{W W}$ & DS & Red. \% & $\mathbf{W W}$ & DS & Red. \% \\
\hline $\mathbf{P}_{1}$ & 21.43 & 13.459 & 37.20 & 37.67 & 27.02 & 7.66 & 21.40 & 29.2 & -36.45 \\
\hline $\mathbf{P}_{2}$ & 26.23 & 17.697 & 32.53 & 46.53 & 40.57 & 6.25 & 23.36 & 30.07 & -28.72 \\
\hline $\mathbf{P}_{\mathbf{3}}$ & 27.57 & 20.366 & 26.13 & 43.23 & 39.92 & 16.73 & 23.49 & 28.01 & -19.24 \\
\hline $\mathbf{P}_{4}$ & 14.96 & 11.934 & 20.23 & 40.62 & 38.08 & 11.83 & 24.22 & 28.545 & -17.86 \\
\hline $\mathbf{P}_{5}$ & 17.10 & 14.003 & 18.11 & 43.16 & 35.94 & 3.18 & 24.74 & 29.135 & -17.76 \\
\hline $\mathbf{P}_{6}$ & 23.67 & 19.306 & 18.44 & 43.28 & 38.16 & 19.59 & 27.35 & 30.345 & -10.95 \\
\hline $\mathbf{P}_{7}$ & 22.31 & 18.282 & 18.05 & 40.89 & 39.59 & 32.11 & 26.62 & 29.355 & -10.27 \\
\hline $\mathbf{P}_{8}$ & 31.14 & 20.038 & 35.65 & 41.81 & 33.62 & 25.68 & 26.45 & 30.685 & -16.01 \\
\hline $\mathbf{P}_{9}$ & 32.59 & 31.342 & 3.83 & 51.01 & 34.63 & 16.79 & 25.40 & 27.975 & -10.14 \\
\hline $\mathbf{P}_{10}$ & 24.47 & 17.919 & 26.77 & 50.71 & 37.69 & 7.66 & 26.14 & 29.665 & -13.49 \\
\hline Mean & 24.15 & 18.43 & 23.69 & 43.89 & 36.52 & 6.25 & 24.91 & 29.30 & -17.62 \\
\hline LSD 5\% & 7.67 & 3.18 & & 3.56 & 2.86 & & 2.96 & 2.42 & \\
\hline
\end{tabular}

Note. $\mathrm{WW}=$ Normal irrigation, $\mathrm{DS}=$ Drought stress, Red. = Reduction percentage.

The $\mathrm{P}_{3}$ have large flag leaf, high flag leaf chlorophyll content and lower flag leaf temperature. This is indicator for drought stress tolerance and more stability for physiological traits. This finding suggests that the $\mathrm{P}_{3}$ 
(NGB10893) found to be higher in its ability to respond to drought and high temperature, thereby tolerance of such this parent could be useful as genetic stock to develop wheat tolerant varieties in breeding programs. Similar results were found by Khatab et al. (2016), whereas they reported that, tolerant genotypes such as Misr1, Misr2, Sids1 and Sham4 genotypes which are classified as tolerant genotypes had the highest chlorophyll content and flag leaf area. The physiological traits were studied previously by many authors, i.e., Masood et al. (2005) said that landraces having more leaf area and lower chlorophyll content. Zareian and Tabatabae (2014) concluded that water stress through with holding at the ear emergence and grain filling phases reduced chlorophyll.

\subsection{Mean Performance of the $F_{1}$ Crosses}

The data in Table 4 showed that the significant differences among $45 \mathrm{~F}_{1}$ crosses in physiological traits under normal irrigation and drought stress. Data in Table 4 showed that the FlA and FLCC of $F_{1}$ crosses were higher than their parents by (8.42 and $20.22 \%)$ and (10.21 and $17.19 \%)$ under normal irrigation and drought stress, respectively. while the flag leaf temperature of $F_{1}$ crosses increased by 0.6 and decreased by $3.5 \%$ more than their parents under normal irrigation and drought stress respectively. Generally, in $\mathrm{F}_{1}$ the drought stress reduced the FLA and FLCC by 12.40 and $9.80 \%$ respectively, also the flag leaf temperature of $\mathrm{F}_{1}$ increased by $3.25{ }^{\circ} \mathrm{C}$ under drought stress. Similar results were found by Almeselmani et al. (2015). 
Table 4. Performance and reduction $\%$ of $F_{1}$ crosses for physiological traits under normal irrigation, drought stress conditions

\begin{tabular}{|c|c|c|c|c|c|c|c|c|c|c|}
\hline \multirow{2}{*}{$\mathbf{F}_{\mathbf{I}}$} & & \multicolumn{3}{|c|}{ Fag leaf area } & \multicolumn{3}{|c|}{ Flag leaf Chl. } & \multicolumn{3}{|c|}{ Flag leaf temperature } \\
\hline & & WW & DS & Red. & WW & DS & Red. & WW & DS & Red. \\
\hline \multirow{9}{*}{$\mathbf{P}_{1}$} & $\mathbf{P}_{2}$ & 23.67 & 18.85 & 20.36 & 50.70 & 43.25 & 14.69 & 24.09 & 27.82 & -15.48 \\
\hline & $\mathbf{P}_{3}$ & 22.69 & 24.58 & -8.33 & 52.23 & 41.63 & 20.29 & 22.47 & 27.83 & -23.85 \\
\hline & $\mathbf{P}_{4}$ & 17.38 & 19.70 & -13.35 & 48.85 & 43.73 & 10.48 & 21.73 & 26.58 & -22.32 \\
\hline & $\mathbf{P}_{5}$ & 19.25 & 16.00 & 16.88 & 46.13 & 41.05 & 11.01 & 24.88 & 27.42 & -10.21 \\
\hline & $\mathbf{P}_{6}$ & 22.43 & 22.08 & 1.56 & 48.73 & 42.55 & 12.68 & 21.90 & 28.19 & -28.72 \\
\hline & $\mathbf{P}_{7}$ & 20.31 & 18.44 & 9.21 & 51.65 & 42.33 & 18.04 & 23.65 & 29.23 & -23.59 \\
\hline & $\mathbf{P}_{8}$ & 27.70 & 20.28 & 26.79 & 47.83 & 43.35 & 9.37 & 22.90 & 29.97 & -30.87 \\
\hline & $\mathbf{P}_{9}$ & 32.15 & 27.67 & 13.93 & 52.08 & 43.10 & 17.24 & 23.87 & 27.53 & -15.33 \\
\hline & $\mathbf{P}_{10}$ & 19.59 & 17.88 & 8.73 & 44.65 & 43.83 & 1.84 & 24.65 & 30.50 & -23.73 \\
\hline \multirow{8}{*}{$\mathbf{P}_{2}$} & $\mathbf{P}_{3}$ & 28.90 & 25.99 & 10.07 & 46.82 & 45.63 & 2.54 & 25.77 & 28.72 & -11.45 \\
\hline & $\mathbf{P}_{4}$ & 17.68 & 15.17 & 14.20 & 44.50 & 44.80 & -0.67 & 24.52 & 26.37 & -7.54 \\
\hline & $\mathbf{P}_{5}$ & 20.65 & 15.49 & 24.99 & 47.33 & 43.73 & 7.61 & 23.25 & 27.05 & -16.34 \\
\hline & $\mathbf{P}_{6}$ & 26.74 & 24.18 & 9.57 & 49.88 & 41.45 & 16.90 & 23.67 & 30.35 & -28.22 \\
\hline & $\mathbf{P}_{7}$ & 25.83 & 24.63 & 4.65 & 58.80 & 50.25 & 14.54 & 22.34 & 30.20 & -35.18 \\
\hline & $\mathbf{P}_{8}$ & 34.39 & 25.98 & 24.45 & 48.52 & 43.09 & 11.19 & 23.85 & 28.75 & -20.55 \\
\hline & $\mathbf{P}_{9}$ & 25.17 & 21.02 & 16.49 & 53.83 & 45.25 & 15.94 & 27.62 & 30.93 & -11.98 \\
\hline & $\mathbf{P}_{10}$ & 20.79 & 27.35 & -31.55 & 47.08 & 41.98 & 10.83 & 27.87 & 29.87 & -7.18 \\
\hline \multirow{7}{*}{$\mathbf{P}_{3}$} & $\mathbf{P}_{4}$ & 24.84 & 22.01 & 11.39 & 45.38 & 42.43 & 6.50 & 23.72 & 26.47 & -11.59 \\
\hline & $\mathbf{P}_{5}$ & 26.54 & 21.49 & 19.03 & 49.19 & 45.50 & 7.50 & 22.68 & 26.05 & -14.86 \\
\hline & $\mathbf{P}_{6}$ & 30.66 & 25.60 & 16.50 & 49.50 & 47.45 & 4.14 & 25.43 & 26.55 & -4.40 \\
\hline & $\mathbf{P}_{7}$ & 28.73 & 29.39 & -2.30 & 49.53 & 45.53 & 8.08 & 27.50 & 26.55 & 3.45 \\
\hline & $\mathbf{P}_{8}$ & 33.06 & 31.00 & 6.23 & 49.53 & 41.28 & 16.66 & 24.88 & 25.92 & -4.18 \\
\hline & $\mathbf{P}_{9}$ & 33.85 & 26.91 & 20.50 & 47.93 & 42.00 & 12.37 & 28.22 & 26.68 & 5.46 \\
\hline & $\mathbf{P}_{10}$ & 28.33 & 25.90 & 8.58 & 46.03 & 42.20 & 8.32 & 26.17 & 27.92 & -6.69 \\
\hline \multirow{6}{*}{$\mathbf{P}_{4}$} & $\mathbf{P}_{5}$ & 17.15 & 22.07 & -28.69 & 50.95 & 43.15 & 15.31 & 24.95 & 27.00 & -8.22 \\
\hline & $\mathbf{P}_{6}$ & 18.82 & 17.02 & 9.56 & 46.03 & 42.63 & 7.39 & 23.62 & 25.03 & -5.97 \\
\hline & $\mathbf{P}_{7}$ & 24.40 & 18.78 & 23.03 & 46.58 & 43.40 & 6.83 & 23.42 & 27.22 & -16.23 \\
\hline & $\mathbf{P}_{8}$ & 29.78 & 23.31 & 21.73 & 47.33 & 42.60 & 9.99 & 25.52 & 26.20 & -2.66 \\
\hline & $\mathbf{P}_{9}$ & 28.53 & 21.09 & 26.08 & 47.50 & 41.40 & 12.84 & 23.90 & 27.13 & -13.51 \\
\hline & $\mathbf{P}_{10}$ & 23.62 & 20.02 & 15.24 & 46.23 & 43.10 & 6.77 & 22.63 & 27.75 & -22.62 \\
\hline \multirow{5}{*}{$\mathbf{P}_{5}$} & $\mathbf{P}_{6}$ & 26.17 & 19.41 & 25.83 & 44.80 & 41.90 & 6.47 & 23.37 & 26.63 & -13.95 \\
\hline & $\mathbf{P}_{7}$ & 26.80 & 21.60 & 19.40 & 45.45 & 43.20 & 4.95 & 23.52 & 27.47 & -16.79 \\
\hline & $\mathbf{P}_{8}$ & 24.83 & 22.25 & 10.39 & 46.88 & 41.35 & 11.80 & 24.57 & 29.17 & -18.72 \\
\hline & $\mathbf{P}_{9}$ & 26.08 & 20.50 & 21.40 & 51.90 & 44.15 & 14.93 & 25.10 & 28.22 & -12.43 \\
\hline & $\mathbf{P}_{10}$ & 25.60 & 17.33 & 32.30 & 41.80 & 43.35 & -3.71 & 25.62 & 31.37 & -22.44 \\
\hline \multirow{4}{*}{$\mathbf{P}_{6}$} & $\mathbf{P}_{7}$ & 25.82 & 23.18 & 10.22 & 52.53 & 36.45 & 30.61 & 26.35 & 30.80 & -16.89 \\
\hline & $\mathbf{P}_{8}$ & 27.49 & 24.82 & 9.71 & 56.25 & 49.01 & 12.87 & 27.40 & 32.84 & -19.85 \\
\hline & $\mathbf{P}_{9}$ & 34.61 & 29.37 & 15.14 & 45.88 & 51.00 & -11.16 & 26.00 & 29.25 & -12.50 \\
\hline & $\mathbf{P}_{10}$ & 25.95 & 24.19 & 6.78 & 50.05 & 47.55 & 5.00 & 25.95 & 29.55 & -13.87 \\
\hline \multirow{3}{*}{$\mathbf{P}_{7}$} & $\mathbf{P}_{8}$ & 28.51 & 23.56 & 17.36 & 46.13 & 46.43 & -0.65 & 29.47 & 30.10 & -2.14 \\
\hline & $\mathbf{P}_{9}$ & 31.40 & 27.79 & 11.50 & 52.98 & 47.43 & 10.48 & 27.42 & 29.10 & -6.13 \\
\hline & $\mathbf{P}_{10}$ & 28.57 & 24.24 & 15.16 & 51.73 & 48.83 & 5.61 & 28.68 & 30.00 & -4.60 \\
\hline \multirow{2}{*}{$\mathbf{P}_{8}$} & $\mathbf{P}_{9}$ & 34.08 & 33.42 & 1.94 & 50.43 & 48.85 & 3.13 & 28.83 & 28.85 & -0.07 \\
\hline & $\mathbf{P}_{10}$ & 34.84 & 29.15 & 16.33 & 48.93 & 43.68 & 10.73 & 27.02 & 27.57 & -2.04 \\
\hline $\mathbf{P}_{9}$ & $\mathbf{P}_{10}$ & 32.20 & 28.87 & 10.34 & 53.30 & 47.88 & 10.17 & 26.88 & 29.32 & -9.08 \\
\hline \multirow{2}{*}{\multicolumn{2}{|c|}{$\begin{array}{l}\text { Mean } \\
\text { LSD 5\% }\end{array}$}} & 26.37 & 23.10 & 12.40 & 48.89 & 44.10 & 9.80 & 25.06 & 28.31 & -12.89 \\
\hline & & 3.67 & 4.32 & & 4.9693 & 7.32 & & 1.97 & 2.12 & \\
\hline
\end{tabular}

Note. $\mathrm{WW}=$ Normal irrigation, $\mathrm{DS}=$ Drought stress, Red. = Reduction percentage.

The largest flag leaf (34.61 and $\left.29.37 \mathrm{~cm}^{2}\right)$ and $\left(33.42\right.$ and $34.08 \mathrm{~cm}^{2}$ ) were found in $\mathrm{P}_{6} \times \mathrm{P}_{9}$ and $\mathrm{P}_{8} \times \mathrm{P}_{9}$ under well water and drought stress respectively. This is an indicator for efficiency of these $F_{1}$ crosses in 
photosynthesis process under drought stress. The highest values of flag chlorophyll content (58.80 and 56.5 SPAD) and (50.25 and 49.01 SPAD) were found in the $\mathrm{P}_{2} \times \mathrm{P}_{7}$ and $\mathrm{P}_{6} \times \mathrm{P}_{8} \mathrm{~F}_{1}$ crosses under normal irrigation and drought stress, respectively. Furthermore, FLA reduced under drought stress of $\mathrm{P}_{1} \times \mathrm{P}_{8}$ and $\mathrm{P}_{4} \times \mathrm{P}_{9}$ by 16.79 , 26.08 and $32.30 \%$ respectively. The $\mathrm{F}_{1}$ of $\mathrm{P}_{2} \times \mathrm{P}_{7}$ and $\mathrm{P}_{6} \times \mathrm{P}_{8}$ were the highest FLCC (58.80 and 56.25) and (50.25 and 49.01) under normal irrigation and drought stress respectively. The $\mathrm{F}_{1}$ crosses $\left(\mathrm{P}_{1} \times \mathrm{P}_{3}\right),\left(\mathrm{P}_{1} \times \mathrm{P}_{4}\right),\left(\mathrm{P}_{1}\right.$ $\left.\times \mathrm{P}_{6}\right),\left(\mathrm{P}_{2} \times \mathrm{P}_{7}\right)$ and $\left(\mathrm{P}_{4} \times \mathrm{P}_{10}\right)$ were the lowest FLT $\left(22.47,21.73,21.90,22.34\right.$ and $\left.22.36{ }^{\circ} \mathrm{C}\right)$ under normal irrigation and increased by $\left(5.36,4.85,6.29,7.86\right.$ and $\left.5.12{ }^{\circ} \mathrm{C}\right)$ in drought stress respectively. Meanwhile, the crosses $\left(\mathrm{P}_{4} \times \mathrm{P}_{8}\right),\left(\mathrm{P}_{7} \times \mathrm{P}_{8}\right),\left(\mathrm{P}_{8} \times \mathrm{P}_{9}\right)$ and $\left(\mathrm{P}_{8} \times \mathrm{P}_{10}\right)$ did not affected by drought stress in FLT.

\subsection{Heterosis and Heterobeltiosis in $F_{1}$ Crosses}

Percentages of heterosis relative to the mid parent (Table 5) and best parent (Table 6) of $F_{1}$ crosses for studied traits under normal irrigation, drought stress and over two conditions are presented. The most desirable heterotic effects were considered as the largest positive heterosis estimates for Flag leaf area (FLA) and Flag leaf chlorophyll content (FLCC), and the lowest negative for Flag leaf temperature (FLT). Average heterosis across all $\mathrm{F}_{1}$ hybrids was preceded significant at $5 \%$ and/or $1 \%$ probability for FLA and FLCC under normal irrigation, drought stress and combined analysis, with exceptions the cross $\mathrm{P}_{4} \times \mathrm{P}_{5}$ was insignificant under the three drought levels for mid and best parents (Table 5). These results were confirmed by Said (2014), and Sharma and Uddin (2020), they reported that high heterosis of bread wheat hybrids was observed for all studied characters under both water treatments in the two crosses, and chlorophyll content (CC) in the first cross. While the crosses $\left(\mathrm{P}_{2} \times\right.$ $\left.\mathrm{P}_{7}\right),\left(\mathrm{P}_{2} \times \mathrm{P}_{9}\right),\left(\mathrm{P}_{2} \times \mathrm{P}_{10}\right)$ and $\left(\mathrm{P}_{3} \times \mathrm{P}_{9}\right)$ were exhibited $\mathrm{H}_{\mathrm{MP}}$ for FLT under well water, the crosses $\left(\mathrm{P}_{3} \times \mathrm{P}_{8}\right)$ and $\left(\mathrm{P}_{4}\right.$ $\left.\times \mathrm{P}_{8}\right)$ were significant of $\mathrm{H}_{\mathrm{MP}}$ under drought stress, and $\left(\mathrm{P}_{5} \times \mathrm{P}_{6}\right)$ expressed desirable significant $\mathrm{H}_{\mathrm{MP}}$ under the normal irrigation, drought stress and combined. Akinci (2009) revealed that heterosis percentages in bread wheat crosses for high-parent and mid-parent were $-2.16 \%$ and $-0.74 \%$ for heading date. Mostly, the interesting desirable $\mathrm{H}_{\mathrm{MP}}$ of the $\mathrm{F}_{1}$ crosses were $\mathrm{P}_{4} \times \mathrm{P}_{8}\left(29.22,45.81\right.$ and 36.01\%) for FLA, $\mathrm{P}_{6} \times \mathrm{P}_{8}(32.21,36.54$ and $34.20 \%)$ for FLCC and $\mathrm{P}_{5} \times \mathrm{P}_{6}(10.27,-10.46$ and $-10.36 \%)$ for FLT under normal irrigation drought stress and combined over two conditions, respectively. The heterosis related to the best parent $\left(\mathrm{H}_{\mathrm{BP}}\right)$ presented in Table 6 . The largest positive $\mathrm{H}_{\mathrm{BP}}$ were recorded for FLA in the $\mathrm{F}_{1}$ crosses $\mathrm{P}_{5} \times \mathrm{P}_{7}(20.09 \%)$ under normal irrigation, $\mathrm{P}_{6} \times$ $\mathrm{P}_{5}(57.59$ and $26.10 \%)$ under both of drought stress and combined. The $\mathrm{P}_{6} \times \mathrm{P}_{8}$ was the largest $\mathrm{H}_{\mathrm{BP}}(29.97$ and 29.24\%) under non stress and combined, and the cross $\mathrm{P}_{8} \times \mathrm{P}_{9}$ was the largest $\mathrm{H}_{\mathrm{MP}}(43.15 \%)$ under drought stress for FLCC, also the cross $\mathrm{P}_{1} \times \mathrm{P}_{6}(-19.91 \%)$ and $\mathrm{P}_{2} \times \mathrm{P}_{7}(-16.07 \%)$ were the most desirable $\mathrm{H}_{\mathrm{BP}}$ for FLT under non stress, and $\mathrm{P}_{4} \times \mathrm{P}_{6}$ were the largest $\mathrm{H}_{\mathrm{BP}}(-17.31$ and -16.67$)$ under drought stress and combined analysis (see Table 6). These finding are in line with those obtained by Jatoi et al. (2014) revealed that the $F_{1}$ crosses, i.e., $($ TD- $1 \times$ TJ-83, Kiran $\times$ Sarsabz), $($ Kiran $\times$ Moomaland) and (Sarsabz $\times$ Moomal) showed greater mid and high parent heterotic response under both environments for leaf area.

\subsection{General Combining Ability Estimates (GCA)}

Estimates of GCA effects of parents for the studied traits under normal irrigation and drought stress are presented in Table (7). Favorable significant GCA effects were expressed by negative estimates for FLT. The data showed that the $\mathrm{P}_{9}, \mathrm{P}_{8}$ and $\mathrm{P}_{3}$ were the best general combiner for FLA which is ranked as 1 st, $2^{\text {nd }}$ and $3^{\text {rd }}$, respectively under normal irrigation and drought stress. While the parents $\mathrm{P}_{2}, \mathrm{P}_{7}$ and $\mathrm{P}_{9}$ were the best general combiner for FLCC, which were ranked as $\left(2^{\text {nd }}, 3^{\text {rd }}\right.$ and 1 st $)$ under normal irrigation and $\left(2^{\text {nd }}, 1^{\text {st }}\right.$ and $\left.3^{\text {rd }}\right)$ under drought stress. Therefor the parents $\mathrm{P}_{1}, \mathrm{P}_{4}$ and $\mathrm{P}_{5}$ were the best general combiner for FLT and ranked as $\left(10^{\text {th }}, 9^{\text {th }}\right.$ and $\left.8^{\text {th }}\right)$ under normal irrigation, also the $\mathrm{P}_{3}, \mathrm{P}_{4}$ and $\mathrm{P}_{5}$ were the best general combiner for FLT and ranked as $\left(9^{\text {th }}, 10^{\text {th }}\right.$ and $\left.8^{\text {th }}\right)$ under drought stress conditions. These results are agreement with those obtained by Ahmad (2010) he found that the best general combiners were $\mathrm{P}_{1}, \mathrm{P}_{4}$ and $\mathrm{P}_{6}$ (earlier) for days to $50 \%$ blooming. 
Table 5. Heterosis of $F_{1}$ related to Mid-Parents for physiological traits under normal irrigation, stress conditions and overall, two environments

\begin{tabular}{|c|c|c|c|c|c|c|c|c|c|c|}
\hline \multirow{2}{*}{$\mathbf{F}_{\mathbf{I}}$} & & \multicolumn{3}{|c|}{ Flag leaf area } & \multicolumn{3}{|c|}{ Flag leaf chlorophyll con. } & \multicolumn{3}{|c|}{ Flag leaf temperature } \\
\hline & & $\mathbf{W W}$ & DS & Comb. & WW & DS & Comb & WW & DS & Comb. \\
\hline \multirow{9}{*}{$\mathbf{P}_{1}$} & $\mathbf{P}_{2}$ & -0.66 & $21.03 * *$ & $7.91 * *$ & $20.43 * *$ & $27.98 * *$ & $23.79 * *$ & 7.65 & -6.13 & -0.21 \\
\hline & $\mathbf{P}_{3}$ & $-7.38^{*}$ & $45.31 * *$ & $14.14 * *$ & $29.11 * *$ & $24.37 * *$ & $26.96^{* *}$ & 0.11 & -2.70 & -1.47 \\
\hline & $\mathbf{P}_{4}$ & -4.47 & $55.14 * *$ & $20.03 * *$ & $24.79 * *$ & $34.33 * *$ & $29.12 * *$ & -4.71 & -7.93 & -6.51 \\
\hline & $\mathbf{P}_{5}$ & -0.04 & $16.49 * *$ & $6.84^{*}$ & $14.13^{* *}$ & $30.40 * *$ & $21.25 * *$ & 7.86 & -6.00 & 0.12 \\
\hline & $\mathbf{P}_{6}$ & -0.53 & $34.79 * *$ & $14.33 * *$ & $20.38 * *$ & $30.55 * *$ & $24.92 * *$ & -10.14 & -5.33 & -7.50 \\
\hline & $\mathbf{P}_{7}$ & $-7.11^{*}$ & $16.20 * *$ & 2.69 & $31.49^{* *}$ & $27.08 * *$ & $29.47 * *$ & -1.49 & -0.15 & -0.75 \\
\hline & $\mathbf{P}_{8}$ & 5.40 & $21.06^{* *}$ & $11.50 * *$ & $20.34 * *$ & $42.97 * *$ & $30.14 * *$ & -4.27 & 0.08 & -1.85 \\
\hline & $\mathbf{P}_{9}$ & $19.05^{* *}$ & $23.50 * *$ & $21.07 * *$ & $17.44 * *$ & $39.82 * *$ & $26.62 * *$ & 1.99 & -3.69 & -1.13 \\
\hline & $P_{10}$ & $-14.62 * *$ & $13.98 * *$ & -3.00 & 1.04 & $35.45 * *$ & $15.59 * *$ & 3.71 & 3.63 & 3.67 \\
\hline \multirow{8}{*}{$\mathbf{P}_{2}$} & $\mathbf{P}_{3}$ & $7.43^{*}$ & $36.57 * *$ & $19.50 * *$ & $4.31 *$ & $13.37 * *$ & $8.59 * *$ & 10.03 & -1.11 & 3.86 \\
\hline & $\mathbf{P}_{4}$ & $-14.18^{* *}$ & 2.39 & -7.25 & 2.12 & $13.92 * *$ & $7.72 * *$ & 3.08 & -10.03 & -4.16 \\
\hline & $\mathbf{P}_{5}$ & -4.66 & -2.28 & -3.66 & $5.53 * *$ & $14.30 * *$ & $9.57 * *$ & -3.31 & -8.62 & -6.24 \\
\hline & $\mathbf{P}_{6}$ & $7.18^{*}$ & $30.67 * *$ & $17.18^{* *}$ & $11.07 * *$ & $5.30 *$ & $8.37 * *$ & -6.64 & 0.47 & -2.78 \\
\hline & $\mathbf{P}_{7}$ & $6.41^{*}$ & $36.91 * *$ & $19.39 * *$ & $34.52 * *$ & $25.37 * *$ & $30.15^{* *}$ & $-10.60 *$ & 1.64 & -3.95 \\
\hline & $\mathbf{P}_{8}$ & $19.90 * *$ & $37.70 * *$ & $26.96^{* *}$ & $9.84 * *$ & $16.15^{* *}$ & $12.72 * *$ & -4.23 & -5.36 & -4.85 \\
\hline & $P_{9}$ & $-14.44 * *$ & $-14.27 * *$ & $-14.36^{* *}$ & $10.36^{* *}$ & $20.35 * *$ & $14.71 * *$ & $13.29 *$ & 6.58 & $9.64 *$ \\
\hline & $\mathbf{P}_{10}$ & $-18.00 * *$ & $53.58 * *$ & $11.53 * *$ & -3.18 & $7.27 * *$ & 1.48 & $12.62 *$ & 0.00 & 5.71 \\
\hline \multirow{7}{*}{$\mathbf{P}_{3}$} & $\mathbf{P}_{4}$ & $16.79 * *$ & $36.26^{* *}$ & $25.20 * *$ & $8.23 * *$ & $8.78 * *$ & $8.50 * *$ & -0.56 & -6.40 & -3.73 \\
\hline & $\mathbf{P}_{5}$ & $18.84 * *$ & $25.08 * *$ & $21.55 * *$ & $13.87 * *$ & $19.96 * *$ & $16.72 * *$ & -5.92 & -8.83 & -7.50 \\
\hline & $\mathbf{P}_{6}$ & $19.67 * *$ & $29.06^{* *}$ & $23.77 * *$ & $14.44 * *$ & $21.54 * *$ & $17.81 * *$ & 0.07 & -9.01 & -4.78 \\
\hline & $\mathbf{P}_{7}$ & $15.18 * *$ & $52.09 * *$ & $31.29 * *$ & $17.75^{* *}$ & $14.51^{* *}$ & $16.18^{* *}$ & 9.77 & -7.43 & 0.59 \\
\hline & $\mathbf{P}_{8}$ & $12.62 * *$ & $53.45 * *$ & $29.27 * *$ & $16.47 * *$ & $12.25^{* *}$ & $14.52 * *$ & -0.33 & $-11.69 *$ & -6.47 \\
\hline & $\mathbf{P}_{9}$ & $12.53 * *$ & 4.10 & $8.63^{* *}$ & 1.71 & $12.68 * *$ & $6.55^{* *}$ & $15.44 *$ & -4.68 & 4.70 \\
\hline & $P_{10}$ & $8.88^{* *}$ & $35.29 * *$ & $20.07 * *$ & -2.01 & $8.75^{* *}$ & 2.86 & 5.47 & -3.19 & 0.81 \\
\hline \multirow{6}{*}{$\mathbf{P}_{4}$} & $\mathbf{P}_{5}$ & 7.02 & $70.16^{* *}$ & $35.26^{* *}$ & $21.63 * *$ & $16.59 * *$ & $19.26^{* *}$ & 1.94 & -6.38 & -2.56 \\
\hline & $\mathbf{P}_{6}$ & -2.54 & 8.94 & 2.60 & $9.71 * *$ & $11.82 * *$ & $10.72 * *$ & -8.39 & $-14.98 * *$ & $-11.91 *$ \\
\hline & $\mathbf{P}_{7}$ & $30.95 * *$ & $24.28 * *$ & $27.97 * *$ & $14.28 * *$ & $11.75^{* *}$ & $13.05 * *$ & -7.86 & -5.99 & -6.86 \\
\hline & $\mathbf{P}_{8}$ & $29.22 * *$ & $45.81 * *$ & $36.01 * *$ & $14.82 * *$ & $18.83^{* *}$ & $16.69 * *$ & 0.74 & $-11.53 *$ & -5.88 \\
\hline & $\mathbf{P}_{9}$ & $20.00 * *$ & -2.52 & $9.27 * *$ & 3.68 & $13.88 * *$ & $8.19 * *$ & -3.66 & -3.99 & -3.83 \\
\hline & $\mathbf{P}_{10}$ & $19.83 * *$ & $34.12 * *$ & $25.99 * *$ & 1.23 & $13.77 * *$ & $6.91 * *$ & -10.10 & -4.66 & -7.18 \\
\hline \multirow{5}{*}{$\mathbf{P}_{5}$} & $\mathbf{P}_{6}$ & $28.38 * *$ & $16.55^{* *}$ & $23.06^{* *}$ & 3.66 & $13.09 * *$ & $8.01^{* *}$ & $-10.27 *$ & $-10.45^{*}$ & $-10.36^{* *}$ \\
\hline & $\mathbf{P}_{7}$ & $35.99 * *$ & $33.83 * *$ & $35.01 * *$ & $8.15^{* *}$ & $14.39 * *$ & $11.10 * *$ & -8.41 & -6.08 & -7.17 \\
\hline & $\mathbf{P}_{8}$ & 2.94 & $30.72 * *$ & $14.43 * *$ & $10.33^{* *}$ & $18.89^{* *}$ & $14.19^{* *}$ & -4.00 & -2.48 & -3.18 \\
\hline & $\mathbf{P}_{9}$ & 4.95 & $-9.59 * *$ & -1.98 & $10.23^{* *}$ & $25.12 * *$ & $16.61 * *$ & 0.13 & -1.18 & -0.57 \\
\hline & $\mathbf{P}_{10}$ & $23.18 * *$ & 8.56 & $16.83 * *$ & $-10.94 * *$ & $17.75^{* *}$ & 1.67 & 0.71 & 6.69 & 3.92 \\
\hline \multirow{4}{*}{$P_{6}$} & $\mathbf{P}_{7}$ & $12.31 * *$ & $23.35^{* *}$ & $17.28 * *$ & $24.81^{* *}$ & $-6.24^{* *}$ & $9.90^{* *}$ & -2.34 & 3.18 & 0.56 \\
\hline & $\mathbf{P}_{8}$ & 0.31 & $26.17 * *$ & $11.12 * *$ & $32.21 * *$ & $36.54 * *$ & $34.20 * *$ & 1.88 & 7.61 & 4.92 \\
\hline & $\mathbf{P}_{9}$ & $23.01 * *$ & $15.98 * *$ & $19.68 * *$ & -2.69 & $40.13 * *$ & $15.96^{* *}$ & -1.41 & 0.31 & -0.51 \\
\hline & $\mathbf{P}_{10}$ & $7.80 *$ & $29.99 * *$ & $17.48 * *$ & $6.50 * *$ & $25.38 * *$ & $14.93 * *$ & -2.95 & -1.52 & -2.19 \\
\hline \multirow{3}{*}{$\mathbf{P}_{7}$} & $\mathbf{P}_{8}$ & $6.65^{*}$ & $22.96^{* *}$ & $13.47 * *$ & $11.55^{* *}$ & $26.83 * *$ & $18.72 * *$ & 11.07 & 0.27 & 5.33 \\
\hline & $\mathbf{P}_{9}$ & $14.39 * *$ & $11.99 * *$ & $13.25^{* *}$ & $15.29 * *$ & $27.80^{* *}$ & $20.88^{* *}$ & 5.42 & 1.52 & 3.37 \\
\hline & $\mathbf{P}_{10}$ & $22.12 * *$ & $33.93 * *$ & $27.27 * *$ & $12.94 * *$ & $26.36^{* *}$ & $19.08 * *$ & 8.75 & 1.66 & 5.01 \\
\hline \multirow{2}{*}{$\mathbf{P}_{8}$} & $\mathbf{P}_{9}$ & $6.96^{* *}$ & $30.11 * *$ & $17.29 * *$ & $8.65^{* *}$ & $43.15^{* *}$ & $23.27 * *$ & 11.23 & -1.64 & 4.40 \\
\hline & $\mathbf{P}_{10}$ & $25.31 * *$ & $53.59 * *$ & $36.79 * *$ & $5.76^{* *}$ & $22.49 * *$ & $13.04 * *$ & 2.76 & -8.64 & -3.33 \\
\hline $\mathbf{P}_{9}$ & $\mathbf{P}_{10}$ & $12.86^{* *}$ & $17.22 * *$ & $14.88^{* *}$ & $4.80^{* *}$ & $32.40 * *$ & $16.27 * *$ & 4.33 & 1.72 & 2.95 \\
\hline
\end{tabular}

Note. $\mathrm{WW}=$ Normal irrigation, $\mathrm{DS}=$ Drought stress, $\mathrm{Comb}=$ Combined over two conditions. $*=$ significant differences at $5 \%$ levels, $* *=$ high significant differences at $1 \%$ levels. 
Table 6. Heterosis of $F_{1}$ related to best-Parents for physiological traits under normal irrigation, stress conditions and overall, two environments

\begin{tabular}{|c|c|c|c|c|c|c|c|c|c|c|}
\hline \multirow{2}{*}{$\mathbf{F}_{1}$} & & \multicolumn{3}{|c|}{ Flag leaf area } & \multicolumn{3}{|c|}{ Flag leaf chlorophyll con. } & \multicolumn{3}{|c|}{ Flag leaf temperature } \\
\hline & & $\mathbf{W W}$ & DS & Comb. & $\mathbf{W W}$ & DS & Comb & WW & DS & Comb. \\
\hline \multirow{9}{*}{$\mathbf{P}_{1}$} & $\mathbf{P}_{2}$ & $-9.76^{* *}$ & 6.54 & -3.20 & $8.96 * *$ & $6.61 *$ & $7.86^{* *}$ & 3.15 & -7.49 & -2.85 \\
\hline & $\mathbf{P}_{3}$ & $-17.70 * *$ & $20.67 * *$ & -1.41 & $20.81 * *$ & 4.27 & $12.87 * *$ & -4.34 & -4.68 & -2.32 \\
\hline & $\mathbf{P}_{4}$ & $-18.89 * *$ & $46.35^{* *}$ & 6.28 & $20.26^{* *}$ & $14.82 * *$ & $17.63 * *$ & -10.25 & -8.96 & -8.42 \\
\hline & $\mathbf{P}_{5}$ & $-10.14^{*}$ & $14.23 *$ & 1.04 & $6.87 * *$ & $14.22 * *$ & $10.21 * *$ & 0.59 & -6.11 & -2.92 \\
\hline & $\mathbf{P}_{6}$ & -5.25 & $14.38 * *$ & 3.57 & $12.58 * *$ & $11.49 * *$ & $12.07 * *$ & $-19.91 * *$ & -7.11 & $-13.18 * *$ \\
\hline & $\mathbf{P}_{7}$ & $-8.96^{*}$ & 0.88 & -4.53 & $26.31 * *$ & $6.91 * *$ & $16.77 * *$ & -11.14 & -0.42 & -5.51 \\
\hline & $\mathbf{P}_{8}$ & $-11.04 * *$ & 1.19 & $-6.25^{*}$ & $14.39 * *$ & $28.94 * *$ & $20.87 * *$ & -13.41 & -2.34 & -7.46 \\
\hline & $\mathbf{P}_{9}$ & -1.34 & $-11.73 * *$ & $-6.43 * *$ & 2.09 & $24.46^{* *}$ & $11.13^{* *}$ & -6.04 & -5.71 & -3.70 \\
\hline & $P_{10}$ & $-19.93 * *$ & -0.20 & $-11.59 * *$ & $-11.95 * *$ & $16.28 * *$ & 0.09 & -5.68 & 2.81 & -1.16 \\
\hline \multirow{8}{*}{$\mathbf{P}_{2}$} & $\mathbf{P}_{3}$ & 4.82 & $27.62 * *$ & $14.50 * *$ & 0.61 & $12.46^{* *}$ & $6.13^{* *}$ & 9.72 & -4.50 & 1.98 \\
\hline & $\mathbf{P}_{4}$ & $-32.62 * *$ & $-14.28 * *$ & $-25.24 * *$ & $-4.36^{*}$ & $10.43 * *$ & 2.53 & 1.25 & $-12.31 *$ & -4.76 \\
\hline & $\mathbf{P}_{5}$ & $-21.26^{* *}$ & -12.48 & $-17.73 * *$ & 1.71 & $7.78^{*}$ & $4.54^{* *}$ & -6.00 & -10.04 & -6.63 \\
\hline & $\mathbf{P}_{6}$ & 1.95 & $25.23 * *$ & $15.91^{* *}$ & $7.19^{* *}$ & 2.17 & $4.85^{* *}$ & $-13.45^{*}$ & 0.02 & -6.37 \\
\hline & $\mathbf{P}_{7}$ & -1.53 & $34.72 * *$ & $14.86^{* *}$ & $26.37 * *$ & $23.86^{* *}$ & $25.20 * *$ & $-16.07 *$ & 0.43 & -6.14 \\
\hline & $\mathbf{P}_{8}$ & $10.45^{* *}$ & $29.66^{* *}$ & $17.97 * *$ & 4.27 & $6.20 *$ & $5.17 * *$ & -9.83 & -6.31 & -7.94 \\
\hline & $P_{9}$ & $-22.78 * *$ & $-32.93 * *$ & $-27.76^{* *}$ & $5.52 *$ & $11.54 * *$ & $13.75^{* *}$ & 8.73 & 2.87 & $9.59 *$ \\
\hline & $\mathbf{P}_{10}$ & $-20.76^{* *}$ & $52.63 * *$ & $9.57 * *$ & $-7.17 * *$ & 3.46 & 0.74 & 6.63 & -0.68 & 3.47 \\
\hline \multirow{7}{*}{$\mathbf{P}_{3}$} & $\mathbf{P}_{4}$ & $-9.93 * *$ & 8.05 & -2.29 & $4.96^{*}$ & $6.28^{*}$ & $5.59 * *$ & -2.06 & -7.28 & -4.88 \\
\hline & $\mathbf{P}_{5}$ & -3.74 & 5.54 & 0.20 & $13.78^{* *}$ & $13.98 * *$ & $13.87^{* *}$ & -8.30 & -10.59 & $-9.54 *$ \\
\hline & $\mathbf{P}_{6}$ & $11.20 * *$ & $25.70 * *$ & $17.36^{* *}$ & $14.37 * *$ & $18.86^{* *}$ & $16.60 * *$ & -6.99 & $-12.51 *$ & $-9.89^{*}$ \\
\hline & $\mathbf{P}_{7}$ & 4.20 & $44.30 * *$ & $21.23 * *$ & $14.56^{* *}$ & $14.04 * *$ & $14.31 * *$ & 3.32 & -9.56 & -3.43 \\
\hline & $\mathbf{P}_{8}$ & $6.17 *$ & $52.21 * *$ & $25.18^{* *}$ & $14.56^{* *}$ & 3.39 & $9.20 * *$ & -5.91 & $-15.54 * *$ & $-11.08 *$ \\
\hline & $\mathbf{P}_{9}$ & 3.87 & $-14.13 * *$ & $-4.96^{*}$ & $-6.05 * *$ & $5.21 *$ & $5.00 * *$ & 11.09 & -4.74 & 2.86 \\
\hline & $P_{10}$ & 2.75 & $27.16^{* *}$ & $13.12 * *$ & $-9.24 * *$ & $5.71 *$ & -0.20 & 0.12 & -5.89 & -3.08 \\
\hline \multirow{6}{*}{$\mathbf{P}_{4}$} & $\mathbf{P}_{5}$ & 0.32 & $57.59 * *$ & $26.10 * *$ & $18.05 * *$ & $13.31 * *$ & $18.96^{* *}$ & 0.87 & -7.33 & -3.56 \\
\hline & $\mathbf{P}_{6}$ & $-20.48 * *$ & $-11.86^{*}$ & $-16.60 * *$ & $6.34 * *$ & $11.70^{* *}$ & $8.85^{* *}$ & $-13.63 *$ & $-17.51 * *$ & $-15.67 * *$ \\
\hline & $\mathbf{P}_{7}$ & $9.37 *$ & 2.70 & $6.37 *$ & $13.90^{* *}$ & $9.62 * *$ & $11.80^{* *}$ & -12.02 & -7.28 & $-9.53^{*}$ \\
\hline & $\mathbf{P}_{8}$ & -4.36 & $16.32 * *$ & 3.74 & $13.19^{* *}$ & $11.87 * *$ & $14.26^{* *}$ & -3.51 & $-14.62 *$ & $-9.48^{*}$ \\
\hline & $\mathbf{P}_{9}$ & $-12.46^{* *}$ & $-32.70 * *$ & $-22.39 * *$ & $-6.88 * *$ & $8.72 * *$ & $3.81 *$ & -5.91 & -4.95 & -4.39 \\
\hline & $\mathbf{P}_{10}$ & -3.47 & $11.72 *$ & 2.96 & $-8.84 * *$ & $13.18^{* *}$ & 1.05 & -13.40 & -6.46 & $-9.71 *$ \\
\hline \multirow{5}{*}{$\mathbf{P}_{5}$} & $\mathbf{P}_{6}$ & $10.55 * *$ & 0.54 & $6.06^{*}$ & 3.51 & $9.80 * *$ & $6.46^{* *}$ & $-14.55^{*}$ & $-12.23 *$ & $-13.33 * *$ \\
\hline & $\mathbf{P}_{7}$ & $20.09 * *$ & $18.17 * *$ & $19.22 * *$ & $5.31^{*}$ & $9.12 * *$ & $10.15^{* *}$ & -11.64 & -6.43 & -8.91 \\
\hline & $\mathbf{P}_{8}$ & $-20.28 * *$ & $11.03^{*}$ & $-8.02 * *$ & $8.61 * *$ & $15.05^{* *}$ & $11.54 * *$ & -7.10 & -4.95 & -5.94 \\
\hline & $\mathbf{P}_{9}$ & $-20.00 * *$ & $-34.60 * *$ & $-27.15^{* *}$ & 1.74 & $22.84 * *$ & $12.16^{* *}$ & -1.18 & -3.15 & -1.03 \\
\hline & $\mathbf{P}_{10}$ & 4.62 & -3.30 & 1.27 & $-17.57 * *$ & $15.02 * *$ & -3.68 & -1.98 & 5.74 & 2.12 \\
\hline \multirow{4}{*}{$\mathbf{P}_{6}$} & $\mathbf{P}_{7}$ & $9.09 *$ & $20.08^{* *}$ & $14.03 * *$ & $21.36^{* *}$ & $-7.93 * *$ & $9.25 * *$ & -3.64 & 1.50 & -0.94 \\
\hline & $\mathbf{P}_{8}$ & $-11.72 * *$ & $23.87 * *$ & 2.22 & $29.97 * *$ & $28.42 * *$ & $29.24 * *$ & 0.20 & 7.01 & 4.41 \\
\hline & $\mathbf{P}_{9}$ & $6.18^{*}$ & $-6.29 *$ & 0.07 & $-10.07 * *$ & $33.65 * *$ & $13.12^{* *}$ & -4.92 & -3.61 & -4.23 \\
\hline & $\mathbf{P}_{10}$ & 6.04 & $25.32 * *$ & $16.67 * *$ & -1.30 & $24.61 * *$ & $10.41 * *$ & -5.10 & -2.62 & -3.80 \\
\hline \multirow{3}{*}{$\mathbf{P}_{7}$} & $\mathbf{P}_{8}^{-}$ & $-8.46^{* *}$ & $17.58^{* *}$ & 1.74 & $10.32 * *$ & $17.26^{* *}$ & $15.00 * *$ & 10.71 & -1.91 & $4.26^{-}$ \\
\hline & $\mathbf{P}_{9}$ & -3.65 & $-11.35^{* *}$ & -7.42 & 3.85 & $19.79 * *$ & $17.23 * *$ & 3.01 & -0.87 & 0.98 \\
\hline & $\mathbf{P}_{10}$ & $16.74 * *$ & $32.60 * *$ & $24.58 * *$ & 2.00 & $23.33 * *$ & $13.74 * *$ & 7.77 & 1.13 & 4.85 \\
\hline \multirow{2}{*}{$\mathbf{P}_{8}$} & $\mathbf{P}_{9}$ & 4.57 & $6.64 *$ & $5.59 * *$ & -1.15 & $41.06^{* *}$ & $15.92 * *$ & 9.03 & -5.98 & 0.97 \\
\hline & $\mathbf{P}_{10}$ & $11.89 * *$ & $45.47 * *$ & $25.04 * *$ & -3.52 & $15.88^{* *}$ & $4.75^{* *}$ & 2.16 & -10.16 & -4.46 \\
\hline $\mathbf{P}_{9}$ & $\mathbf{P}_{10}$ & -1.20 & $-7.88^{*}$ & $-4.47 *$ & $4.49^{*}$ & $27.02 * *$ & $14.45^{* *}$ & 2.86 & -1.17 & 0.72 \\
\hline
\end{tabular}

Note. $\mathrm{WW}=$ Normal irrigation, $\mathrm{DS}=$ Drought stress, $\mathrm{Comb}=$ Combined two conditions. ${ }^{*}=$ significant differences at $5 \%$ levels, $* *=$ high significant differences at $1 \%$ levels. 
Table 7. General combining ability estimates and ranks of the parents for physiological traits under normal irrigation and drought stress conditions

\begin{tabular}{|c|c|c|c|c|c|c|c|c|c|c|c|c|}
\hline \multirow{2}{*}{ Parent } & \multicolumn{4}{|c|}{ Flag leaf area } & \multicolumn{4}{|c|}{ Flag leaf chl. } & \multicolumn{4}{|c|}{ Flag leaf temp. } \\
\hline & $\mathbf{W W}$ & $\mathbf{R}$ & DS & $\mathbf{R}$ & $\mathbf{W W}$ & $\mathbf{R}$ & DS & $\mathbf{R}$ & $\mathbf{W W}$ & $\mathbf{R}$ & DS & $\mathbf{R}$ \\
\hline $\mathrm{P}_{1}$ & $-3.13 * *$ & 8 & $-2.70 * *$ & 8 & -0.80 & 8 & $-2.59 * *$ & 10 & $-1.87 * *$ & 10 & 0.01 & 6 \\
\hline $\mathrm{P}_{2}$ & -0.78 & 7 & -0.89 & 7 & 1.06 & 2 & 0.88 & 2 & $-0.48 *$ & 7 & $0.57^{*}$ & 3 \\
\hline $\mathrm{P}_{3}$ & $2.26 * *$ & 3 & $2.40 * *$ & 3 & -0.44 & 7 & 0.29 & 6 & -0.13 & 6 & $-1.22 * *$ & 9 \\
\hline $\mathrm{P}_{4}$ & $-4.46^{* *}$ & 10 & $-3.48 * *$ & 10 & $-1.94 * *$ & 10 & -0.55 & 8 & $-1.08 * *$ & 9 & $-1.38 * *$ & 10 \\
\hline $\mathrm{P}_{5}$ & $-3.20 * *$ & 9 & $-3.39 * *$ & 9 & $-1.42 *$ & 9 & -0.89 & 9 & $-0.67 *$ & 8 & -0.40 & 8 \\
\hline $\mathrm{P}_{6}$ & 0.03 & 5 & 0.31 & 5 & 0.20 & 5 & 0.53 & 5 & 0.25 & 5 & $0.54^{*}$ & 4 \\
\hline $\mathrm{P}_{7}$ & -0.05 & 6 & 0.28 & 6 & 0.78 & 3 & 1.09 & 1 & $0.85^{* *}$ & 4 & $0.50^{*}$ & 5 \\
\hline $\mathrm{P}_{8}$ & $4.28 * *$ & 2 & $2.42 * *$ & 2 & -0.20 & 6 & -0.26 & 7 & $0.99 * *$ & 3 & $0.61^{*}$ & 2 \\
\hline $\mathrm{P}_{9}$ & $4.80 * *$ & 1 & $4.54 * *$ & 1 & $2.50 * *$ & 1 & 0.86 & 3 & $1.10 * *$ & 1 & -0.04 & 7 \\
\hline $\mathrm{P}_{10}$ & 0.23 & 4 & 0.50 & 4 & 0.28 & 4 & 0.65 & 4 & $1.03 * *$ & 2 & $0.81 * *$ & 1 \\
\hline
\end{tabular}

Note. $\mathrm{WW}=$ Normal irrigation, $\mathrm{DS}=$ Drought stress, $\mathrm{R}=$ Ranks. ${ }^{*}=$ significant differences at $5 \%$ levels, ${ }^{* *}=$ high significant differences at $1 \%$ levels.

\subsection{Specific Combining Ability Estimates (SCA)}

The data presented in Table (8) showed The SCA effects of $45 \mathrm{~F}_{1}$ crosses for physiological traits of flag leaf and their ranks under normal irrigation and drought stress conditions. Totally 12 ( 8 positive and 4 negative) and 11 ( 9 positive and 2 negative) of $F_{1}$ crosses exhibited significant SCA effects for FLA under normal irrigation and drought stress, respectively. Whereas the cross $\left(\mathrm{P}_{1} \times \mathrm{P}_{4}\right)$ had positive (desirable) SCA effect under both of normal irrigation and drought stress. For FLCC 6 and $5 F_{1}$ crosses were significant effects of SCA, 4 crosses each out of them was positive (desirable) under normal irrigation and drought stress. Furthermore, the crosses $\left(\mathrm{P}_{2} \times \mathrm{P}_{7}\right)$ and $\left(\mathrm{P}_{6} \times \mathrm{P}_{8}\right)$ were exhibited positive significantly of SCA effects in the FLCC under both of normal irrigation and drought stress conditions. Similar results were found by Mohamed and Morsy (2013), Gomaa et al. (2014) and Mandal and Madhuri (2016). Regarding to the FLT, 16 (ten positive and six negative) and nine (3 positive and 6 negative) $F_{1}$ crosses were found to be significant effects of SCA under normal irrigation and drought stress.

\subsection{Gene Action, Heritability and Expected Genetic Advance From Selection}

The variance components, heritability and selection gain for physiological traits are presented in Table (9) and figure (1). Under normal irrigation and drought stress conditions as well as the combined data, the additive genetic components of variation $\left(\mathrm{V}_{\mathrm{A}}\right)$ in $\mathrm{F}_{1}$ 's was much greater than dominance component $\left(\mathrm{V}_{\mathrm{D}}\right)$, as expressed by the $\left(\mathrm{V}_{\mathrm{A}} / \mathrm{V}_{\mathrm{D}}\right)$ ratio which was more than unity for the FLA, and FLT under normal irrigation and their combined (Table 9). This indicates that the additive gene effects in $F_{1}$ crosses are more important than dominance and plays the major role in the inheritance of these studied traits. On the other hand, the dominance genetic components of variation $\left(V_{D}\right)$ in $F_{1}$ 's was much greater than additive component $\left(V_{A}\right)$, as expressed by the $\left(\mathrm{V}_{\mathrm{A}} / \mathrm{V}_{\mathrm{D}}\right)$ ratio which was less than unity for the FLCC under normal irrigation, drought stress and their combined. This indicates that the dominance gene effects in $\mathrm{F}_{1}$ crosses are more important than additive and plays the major role in the inheritance of flag leaf chlorophyll content under normal irrigation and drought stress as well as the combined data, except Flag leaf temperature (FLT) under drought stress, where both additive and dominance were of equal importance $\left(\mathrm{V}_{\mathrm{A}} / \mathrm{V}_{\mathrm{D}}=0.96\right.$, equals unity approximately). 
Table 8. Specific combining ability and ranks of $\mathrm{F}_{1}$ crosses for physiological traits under normal irrigation and drought stress conditions

\begin{tabular}{|c|c|c|c|c|c|c|c|c|c|c|c|c|c|}
\hline \multirow{2}{*}{$\mathbf{F}_{1}$} & & \multicolumn{4}{|c|}{ Fag leaf area } & \multicolumn{4}{|c|}{ Flag leaf Chl. } & \multicolumn{4}{|c|}{ Flag leaf temperature } \\
\hline & & $\mathbf{W W}$ & $\mathbf{R}$ & DS & $\mathbf{R}$ & $\mathbf{W W}$ & $\mathbf{R}$ & DS & $\mathbf{R}$ & WW & $\mathbf{R}$ & DS & $\mathbf{R}$ \\
\hline \multirow{9}{*}{$\mathbf{P}_{1}$} & $\mathbf{P}_{2}$ & 1.61 & 14 & 0.19 & 30 & 2.47 & 12 & 2.24 & 15 & $1.40 *$ & 10 & -1.25 & 37 \\
\hline & $\mathbf{P}_{3}$ & -2.40 & 38 & 2.62 & 10 & $5.48 * *$ & 4 & 1.20 & 24 & -0.56 & 30 & 0.56 & 11 \\
\hline & $\mathbf{P}_{4}$ & -1.00 & 32 & $3.63 * *$ & 7 & 3.61 & 6 & 4.14 & 6 & -0.35 & 24 & -0.54 & 28 \\
\hline & $\mathbf{P}_{5}$ & -0.38 & 29 & -0.17 & 32 & 0.37 & 26 & 1.81 & 19 & $2.38 * *$ & 2 & -0.68 & 30 \\
\hline & $\mathbf{P}_{6}$ & -0.44 & 30 & 2.22 & 15 & 1.35 & 20 & 1.89 & 17 & $-1.51^{*}$ & 40 & -0.85 & 32 \\
\hline & $\mathbf{P}_{7}$ & -2.47 & 39 & -1.39 & 34 & 3.70 & 5 & 1.11 & 25 & -0.36 & 25 & 0.24 & 16 \\
\hline & $\mathbf{P}_{8}$ & 0.59 & 23 & -1.70 & 36 & 0.85 & 23 & 3.48 & 10 & -1.26 & 38 & 0.86 & 7 \\
\hline & $\mathbf{P}_{9}$ & $4.52 * *$ & 2 & $3.57 * *$ & 8 & 2.40 & 13 & 2.11 & 16 & -0.40 & 29 & -0.93 & 34 \\
\hline & $P_{10}$ & $-3.48 * *$ & 43 & -2.17 & 39 & -2.81 & 43 & 3.05 & 12 & 0.46 & 15 & 1.19 & 5 \\
\hline \multirow{8}{*}{$\mathbf{P}_{2}$} & $\mathbf{P}_{3}$ & 1.45 & 17 & 2.23 & 14 & -1.79 & 35 & 1.73 & 21 & 1.34 & 11 & 0.89 & 6 \\
\hline & $\mathbf{P}_{4}$ & $-3.05 *$ & 42 & -2.71 & 43 & -2.60 & 42 & 1.74 & 20 & 1.04 & 13 & -1.31 & 39 \\
\hline & $\mathbf{P}_{5}$ & -1.34 & 34 & -2.48 & 42 & -0.29 & 32 & 1.01 & 26 & -0.64 & 32 & $-1.61 *$ & 41 \\
\hline & $\mathbf{P}_{6}$ & 1.52 & 15 & 2.51 & 11 & 0.64 & 24 & -2.68 & 44 & -1.14 & 35 & 0.75 & 8 \\
\hline & $\mathbf{P}_{7}$ & 0.69 & 21 & $2.99 * *$ & 9 & $8.99 * *$ & 1 & $5.56 * *$ & 3 & $-3.07 * *$ & 45 & 0.64 & 9 \\
\hline & $\mathbf{P}_{8}$ & $4.93 * *$ & 1 & 2.20 & 16 & -0.32 & 33 & -0.26 & 37 & $-1.71 * *$ & 43 & -0.92 & 33 \\
\hline & $\mathbf{P}_{9}$ & $-4.83 * *$ & 45 & $-4.88 * *$ & 45 & 2.29 & 14 & 0.78 & 28 & $1.95 * *$ & 5 & $1.91 * *$ & 3 \\
\hline & $\mathbf{P}_{10}$ & $-4.64 * *$ & 44 & $5.49 * *$ & 2 & -2.25 & 40 & -2.28 & 43 & $2.28 * *$ & 3 & -0.01 & 22 \\
\hline \multirow{7}{*}{$\mathbf{P}_{3}$} & $\mathbf{P}_{4}$ & 1.07 & 19 & 0.83 & 22 & -0.23 & 30 & -0.04 & 34 & -0.10 & 22 & 0.58 & 10 \\
\hline & $\mathbf{P}_{5}$ & 1.51 & 16 & 0.23 & 29 & 3.06 & 8 & 3.38 & 11 & $-1.56^{*}$ & 41 & -0.82 & 31 \\
\hline & $\mathbf{P}_{6}$ & 2.40 & 11 & 0.64 & 26 & 1.76 & 16 & 3.91 & 7 & 0.28 & 17 & -1.26 & 38 \\
\hline & $\mathbf{P}_{7}$ & 0.55 & 25 & $4.45 * *$ & 3 & 1.20 & 21 & 1.42 & 23 & $1.75^{* *}$ & 7 & -1.21 & 36 \\
\hline & $\mathbf{P}_{8}$ & 0.56 & 24 & $3.92 * *$ & 6 & 2.18 & 15 & -1.48 & 40 & -1.01 & 34 & $-1.96 * *$ & 42 \\
\hline & $\mathbf{P}_{9}$ & 0.82 & 20 & -2.29 & 41 & -2.12 & 39 & -1.88 & 42 & $2.21 * *$ & 4 & -0.55 & 29 \\
\hline & $\mathbf{P}_{10}$ & -0.13 & 27 & 0.74 & 24 & -1.80 & 36 & -1.46 & 39 & 0.23 & 18 & -0.16 & 23 \\
\hline \multirow{6}{*}{$\mathbf{P}_{4}$} & $\mathbf{P}_{5}$ & -1.16 & 33 & $6.68^{* *}$ & 1 & $6.33 * *$ & 3 & 1.87 & 18 & $1.66^{*}$ & 9 & 0.29 & 14 \\
\hline & $\mathbf{P}_{6}$ & -2.72 & 40 & -2.07 & 38 & -0.22 & 29 & -0.08 & 35 & -0.59 & 31 & $-2.62 * *$ & 45 \\
\hline & $\mathbf{P}_{7}$ & $2.95^{*}$ & 8 & -0.28 & 33 & -0.25 & 31 & 0.14 & 33 & -1.39 & 39 & -0.39 & 27 \\
\hline & $\mathbf{P}_{8}$ & $4.00 * *$ & 5 & 2.11 & 17 & 1.48 & 19 & 0.68 & 29 & 0.57 & 14 & $-1.52 *$ & 40 \\
\hline & $\mathbf{P}_{9}$ & 2.22 & 12 & -2.23 & 40 & -1.05 & 34 & -1.64 & 41 & -1.16 & 36 & 0.06 & 20 \\
\hline & $\mathbf{P}_{10}$ & 1.88 & 13 & 0.75 & 23 & -0.10 & 28 & 0.28 & 32 & $-2.35 * *$ & 44 & -0.17 & 24 \\
\hline \multirow{5}{*}{$\mathbf{P}_{5}$} & $\mathbf{P}_{6}$ & $3.37^{*}$ & 7 & 0.24 & 28 & -1.96 & 38 & -0.46 & 38 & -1.25 & 37 & $-2.00 * *$ & 43 \\
\hline & $\mathbf{P}_{7}$ & $4.08 * *$ & 4 & 2.45 & 12 & -1.88 & 37 & 0.28 & 31 & $-1.70 * *$ & 42 & -1.13 & 35 \\
\hline & $\mathbf{P}_{8}$ & -2.22 & 37 & 0.96 & 21 & 0.52 & 25 & -0.22 & 36 & -0.80 & 33 & 0.47 & 13 \\
\hline & $\mathbf{P}_{9}$ & -1.50 & 35 & $-2.91 *$ & 44 & 2.84 & 9 & 1.46 & 22 & -0.37 & 27 & 0.16 & 18 \\
\hline & $\mathbf{P}_{10}$ & 2.60 & 9 & -2.04 & 37 & $-5.04 * *$ & 45 & 0.87 & 27 & 0.22 & 20 & $2.46 * *$ & 2 \\
\hline \multirow{4}{*}{$\mathbf{P}_{6}$} & $\mathbf{P}_{7}$ & -0.13 & 26 & 0.34 & 27 & 3.57 & 7 & $-7.89 * *$ & 45 & 0.22 & 19 & 1.27 & 4 \\
\hline & $\mathbf{P}_{8}$ & -2.79 & 41 & -0.16 & 31 & $8.27 * *$ & 2 & $6.01 * *$ & 2 & 1.12 & 12 & $3.19 * *$ & 1 \\
\hline & $\mathbf{P}_{9}$ & $3.80 * *$ & 6 & 2.27 & 13 & $-4.81 * *$ & 44 & $6.89 * *$ & 1 & -0.39 & 28 & 0.25 & 15 \\
\hline & $\mathbf{P}_{10}$ & -0.29 & 28 & 1.14 & 20 & 1.59 & 18 & 3.65 & 8 & -0.36 & 26 & -0.29 & 26 \\
\hline \multirow{3}{*}{$\mathbf{P}_{7}$} & $\mathbf{P}_{8}$ & -1.69 & 36 & -1.40 & 35 & -2.43 & 41 & $2.87^{-}$ & 13 & $2.59 * *$ & 1 & $0.50^{-}$ & 12 \\
\hline & $\mathbf{P}_{9}$ & 0.69 & 22 & 0.70 & 25 & 1.72 & 17 & 2.75 & 14 & 0.43 & 16 & 0.15 & 19 \\
\hline & $\mathbf{P}_{10}$ & 2.42 & 10 & 1.20 & 19 & 2.68 & 10 & 4.37 & 5 & $1.77 * *$ & 6 & 0.20 & 17 \\
\hline \multirow{2}{*}{$\mathbf{P}_{8}$} & $\mathbf{P}_{9}$ & -0.97 & 31 & $4.21 * *$ & 4 & 0.14 & 27 & $5.52 * *$ & 4 & $1.70 * *$ & 8 & -0.22 & 25 \\
\hline & $\mathbf{P}_{10}$ & $4.37 * *$ & 3 & $3.98 * *$ & 5 & 0.86 & 22 & 0.56 & 30 & -0.04 & 21 & $-2.35 * *$ & 44 \\
\hline $\mathbf{P}_{9}$ & $\mathbf{P}_{10}$ & 1.20 & 18 & 1.57 & 18 & 2.54 & 11 & 3.64 & 9 & -0.28 & 23 & 0.05 & 21 \\
\hline
\end{tabular}

Note. $\mathrm{WW}=$ Normal irrigation, $\mathrm{DS}=$ Drought stress, $\mathrm{R}=$ Ranks. $*=$ significant differences at $5 \%$ levels, $* *=$ high significant differences at $1 \%$ levels. 


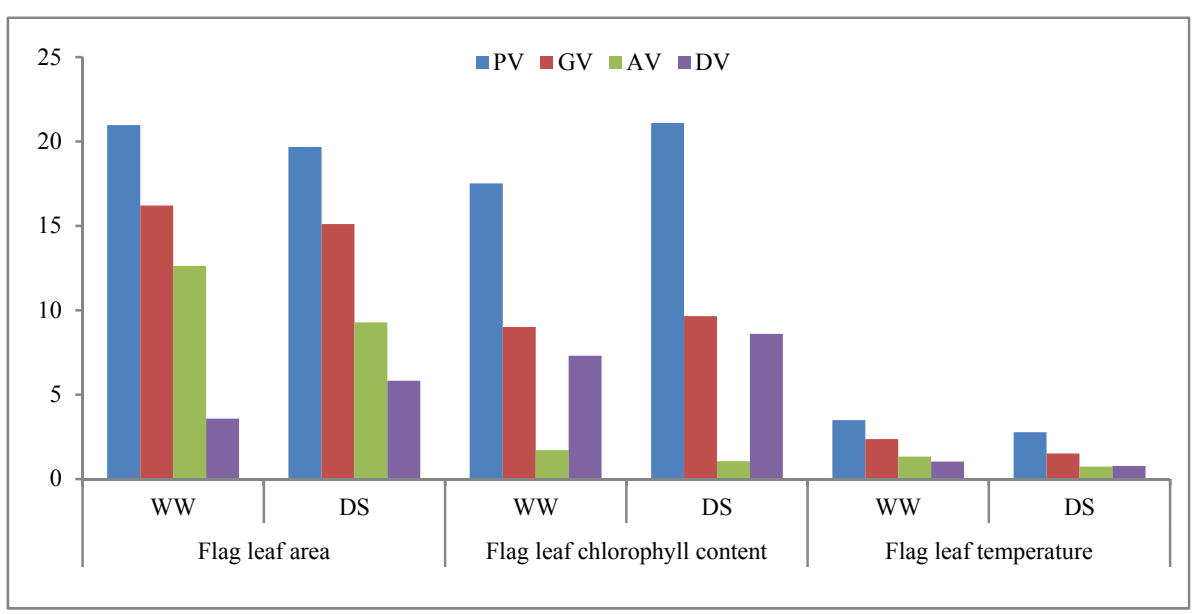

Figure 1. Phenotypic, Genotypic, Additive and Dominance variances under normal irrigation and drought stress conditions for physiological traits

Note. $\mathrm{WW}=$ normal irrigation, $\mathrm{DS}=$ Drought stress, $\mathrm{PV}=$ phenotypic variance, $\mathrm{GV}=$ Genotypic variance, $\mathrm{AV}=$ additive variance, $\mathrm{DV}=$ Dominance variance.

Also, when GCA/SCA ratio was used, it was found that Flag leaf area (FLA) in normal irrigation as well as the combined data, exhibited high GCA/SCA ratio of more than unity, indicating the additive gene action in the inheritance of FLA under normal irrigation. While, the GCA/SCA ratio was expressed as less than unity of FLA under drought stress, FLCC and FLT under normal irrigation and drought stress and combined. Indicating the non-additive gene action could be an important in the inheritance of FLCC and FLT under both two environments and FLA under stressed conditions. On the other hand, El-Hosary et al. (2012), Abul-Naas et al. (2000), they found that the degree of dominance of physiological traits in table (9) showed the over dominance $(a>1)$ for all physiological traits, with exception the FLA under normal irrigation and combined data were inherited by partial dominance $(\mathrm{a}<1)$, this finding suggested that the selection for imprudent of these traits should be delayed to late generation. These results are agreement with those obtained by Qabil (2017), he showed that the dominance components in bread wheat was more than the corresponding additive one for flag leaf area, chlorophyll content. Contrasting, said (2014) reported that the flag leaf chlorophyll content was controlled by the additive type of gene action. Saleem et al. (2016) revealed that the additive gene action was observed for canopy temperature and Chlorophyll ' $a$ ' high GCA/SCA ratio, which exceeded than unity was obtained for leaf temperature (LT) in both treatments and their combined.

In the physiological traits (FLA, FLCC and FLT), the ratio of SCA $\times$ Env./SCA was much higher than the ratios of GCA $\times$ Env./GCA was detected. Such results indicated that non additive effects were much more influenced changes by environmental than GCA. El Hosary et al. (2009a, 2009b) found that non additive type of gene action was much more influence by the environmental condition than additive genetic one for some drought traits. The heritability estimates in the broad sense $\left(\mathrm{H}_{\mathrm{b}}\right)$ in the $\mathrm{F}_{1}$ crosses were high $(60-80 \%)$ in magnitude for FLT under normal irrigation, and FLA under normal irrigation, drought stress and their combined (Table 9), indicating that the genetic variance is the main component of phenotypic variance and that the environment had little effect on the studied $F_{1}$ crosses. Meanwhile the heritability in broad sense $\left(H_{b}\right)$ in the $F_{1}$ crosses were moderate (40-60\%) for FLCC under normal irrigation, drought stress and combined data and FLT under drought stress and combined data, that is meaning that the phenotypic variance as affected by environmental effects as well as the genotypic variance and that the environment had effects on the studied $F_{1}$ crosses. Regarding to the narrow sense heritability $\left(\mathrm{H}_{\mathrm{n}}\right)$ in the $\mathrm{F}_{1}$ crosses was moderate $(40-60 \%)$ for FLA, and were $(60,47$ and $57 \%)$ under normal irrigation, drought stress and their combined. On the other hand, the narrow sense heritability $\left(\mathrm{H}_{\mathrm{n}}\right)$ was low $(<$ $40 \%$ ) for FLCC and FLT under both of two environments and combined analysis. indicating the lower importance of $\mathrm{V}_{\mathrm{A}}$ compared to $\mathrm{V}_{\mathrm{D}}$ in these traits under non-stressed, stressed environments and combined data. 
Table 9. Variance component of physiological traits for Parents and their $\mathrm{F}_{1}$ crosses, under normal irrigation, drought stress conditions and overall two environments

\begin{tabular}{|c|c|c|c|c|c|c|c|c|c|}
\hline & \multicolumn{3}{|c|}{ Flag leaf area } & \multicolumn{3}{|c|}{ Flag leaf chlorophyll content } & \multicolumn{3}{|c|}{ Flag leaf temperature } \\
\hline & WW & DS & Comb. & WW & DS & Comb. & WW & DS & Comb. \\
\hline $\mathbf{V P}$ & 20.97 & 19.68 & 19.17 & 17.51 & 21.09 & 18.26 & 3.49 & 2.77 & 2.55 \\
\hline VG & 16.21 & 15.10 & 14.50 & 9.01 & 9.65 & 8.28 & 2.36 & 1.51 & 1.36 \\
\hline VA & 12.63 & 9.28 & 10.90 & 1.71 & 1.05 & 1.32 & 1.33 & 0.74 & 0.78 \\
\hline VD & 3.58 & 5.82 & 3.60 & 7.30 & 8.60 & 6.96 & 1.03 & 0.77 & 0.58 \\
\hline VA/VD & 3.53 & 1.59 & 3.03 & 0.23 & 0.12 & 0.19 & 1.29 & 0.96 & 1.34 \\
\hline [a] & 0.75 & 1.12 & 0.81 & 2.92 & 4.05 & 3.25 & 1.24 & 1.44 & 1.22 \\
\hline Hn & 0.60 & 0.47 & 0.57 & 0.10 & 0.05 & 0.07 & 0.38 & 0.27 & 0.31 \\
\hline $\mathbf{H b}$ & 0.77 & 0.77 & 0.76 & 0.51 & 0.46 & 0.45 & 0.68 & 0.55 & 0.53 \\
\hline GCA & 6.32 & 4.64 & 5.45 & 0.86 & 0.53 & 0.66 & 0.66 & 0.37 & 0.39 \\
\hline SCA & 3.58 & 5.82 & 3.60 & 7.30 & 8.60 & 6.96 & 1.03 & 0.77 & 0.58 \\
\hline GCA:SCA & 1.77 & 0.80 & 1.52 & 0.12 & 0.06 & 0.10 & 0.65 & 0.48 & 0.68 \\
\hline GCA $\times$ Env $/$ GCA & - & - & 0.02 & - & - & 0.21 & - & - & 0.35 \\
\hline $\mathrm{SCA} \times \mathbf{E n v} / \mathrm{SCA}$ & - & - & 0.43 & - & - & 0.31 & - & - & 0.68 \\
\hline PCV & 89.87 & 94.05 & 89.16 & 60.41 & 70.26 & 63.44 & 37.35 & 31.19 & 30.89 \\
\hline GCV & 79.02 & 82.38 & 77.55 & 43.33 & 47.53 & 42.74 & 30.70 & 23.05 & 22.53 \\
\hline GA & 7.29 & 7.01 & 6.82 & 4.44 & 4.33 & 3.99 & 2.60 & 1.87 & 1.75 \\
\hline GAM & 28.09 & 31.51 & 28.30 & 9.24 & 10.13 & 8.81 & 10.39 & 6.58 & 6.54 \\
\hline
\end{tabular}

Note. $\mathrm{WW}=$ normal irrigation, $\mathrm{DS}=$ drought stress, Comb. $=$ overall, two environments, $\mathrm{PV}=$ Phenotypic variance, $\mathrm{GV}=$ Genotypic variance, $\mathrm{AV}=$ Additive variance, $\mathrm{DV}=$ Dominance variance, $\mathrm{EV}=$ Environmental variance, $\mathrm{Hn}=$ heritability in narrow sense, $\mathrm{Hb}=$ Heritability in broad sense, GCA = General combining ability, $\mathrm{SCA}=$ Specific combining ability, PCV = Phenotypic coefficient of variation, GCV = Genotypic coefficient of variation, $\mathrm{GA}=$ Genetic advance, $\mathrm{GAM}=$ Genetic advance over mean .

These results are agreement with those obtained by many previous authors, whereas Kumar et al. (2015) revealed to the estimates of $\mathrm{h}^{2}$ were found highly significant for flag leaf area, Saleem et al. (2016) reported that canopy temperature and chlorophyll 'a' expressed reasonably high heritability that supports the results of gene action providing an opportunity for early generation selection to use in a breeding program. Khan and Hassan (2017) noticed the high heritability (0.89) was noticed in flag leaf area. Clearly the differences between the phenotypic coefficient of variation (PCV) and genotypic coefficient of variation (GCV) were high (>20) for FLCC and moderate (10-20) for FLA, that is an evidence for improving these traits through the selection is not so easy. Contrast, the differences between PCV and GCV of flag leaf temperature (FLT) were low $(<10)$ that is due to the minimal influence of environment on the expression of these traits, so it easy to select based on the phenotypic values. The high and moderate broad sense heritability coupled with Low $(<10 \%)$ expected genetic gain (GA) from selection based on $F_{1}$ results and assuming 5\% selection intensity (Table 29), which were (7.27, 4.44 and $2.60 \%),(7.01,4.33$ and 1.87\%) and (6.82, 3.99 and 1.75\%) for FLA, FLCC and FLT under normal irrigation, drought stress and their combined respectively.

\section{References}

Abul-Naas, A. A., El-Shamarka, Sh. A., El-Hosary, A. A., \& Darwish, I. H. (2000). Genetical studies on drought susceptibility index for yield and its components in wheat. J. Agric. Sci. Mansoura Univ., 25(12), 7469-7484.

Ahmad, M. S. H. (2010). Combining ability and heterosis estimates for agronomic traits in bread wheat using half diallel analysis. J. Plant Prod., Mansoura Univ., l(11), 1441-1450. https://doi.org/10.21608/jpp.2010. 86591

Akinci, C. (2009). Heterosis and combining ability estimates in $6 \times 6$ half-diallel crosses of durum wheat (Triticum durum desf.) Bulgarian Journal of Agricultural Science, 15(3), 214-22.

Almeselmani, M., Al-Rzak, S., Al-Zubi, A. K., Al-Ghazali, S., Hareri, F., Al-Nassan, M., ... Teixeira Da Silva, J. A. (2015). Evaluation of physiological traits, yield and yield components at two growth stages in 10 durum wheat lines grown under rainfed conditions in southern Syria. Cercetări Agronomiceîn Moldova, 48, 29-49. https://doi.org/10.1515/cerce-2015-0028 
Al-Otayk, S. M. (2010). Performance of yield and stability of wheat genotypes under high stress environments of the central region of Saudi arabia. JKAU: Met., Env. \& Arid Land Agric. Sci., 21(1), 81-92 .https://doi.org/ $10.4197 /$ met.21-1.6

Birsin, M. A. (2005). Effects of removal of some photosynthetic structures on some yield components in wheat. Tarim Bilim Derg., 11, 364-367. https://doi.org/10.1501/Tarimbil_0000000559

Blum, A. (1983). Breeding Programs Improving Drought Resistance to Water Stress. In C. D. Jr. Raper \& P. J. Kramer (Eds.), Crop Reaction to Water and Temperature Stresses in Humid, Temperate Climates (pp. 263-275). Westview Press, Boulder, Colorado, USA.

Boko, M. I., Nyong, A., Vogel, C., Githeko, A., Medany, M., Elasha, B. O., Tabo, R., \& Africa, Y. P. (2007). In M. L. Parry, O. F. Canziani, J. P. Palutikof, P. J. van der Linden, \& C. E. Hanson (Eds.), Climate change, impacts, adaptation and vulnerability (pp. 433-467). IPCC.

Braun, H. J., Atlin, G., \& Payne, T. (2010). In C. R. P. Reynolds (Ed.), Climate change and crop production. CABI, London, UK.

Chukwu, S. C., Okporie, E. O., Onyishi, G. C., Ekwu, L. G., Nwogbaga, A. C., \& Ede, N. V. (2016). Application of diallel analyses in crop improvement. Agric. Biol. J. N. Am., 7(2), 95-106.

Contreras-Moreira, B., Serrano-Notivoli, R., Mohammed, N. E., Casas, A. M., \& Igartua, E. (2019). Genetic association with high-resolution climate data reveals selection footprints in the genomes of barley landraces across the Iberian Peninsula. Molecular Ecology, 28(8), 1994-2012. https://doi.org/10.1111/mec.15009

El Wazziki, H., El Yousfi, B., \& Serghat, S. (2015). Contributions of three upper leaves of wheat, either healthy or inoculated by Bipolaris sorokiniana, to yield and yield components. AJCS, 9(7), 629-637.

El-Hosary, A. A, Omar, S. A., \& Wafaa, A. H. (2009a). Improving wheat production under drought conditions by using diallel crossing system (pp. 70-89). 6th International Plant Breeding Conference, Ismailia, Egypt.

EL-Hosary, A. A., EL-Badawy, M. E. M., Mustafa, A. K., \& EL-Shal, M. H. (2012). Breeding bread wheat for tolerance to drought stress. Minufiya J. Agric. Res., 37(2), 351-369.

El-Hosary, A. A., Omar, S. A., \& Wafaa, A. H. (2009b). Improving wheat production under drought conditions by using diallel crossing system (pp. 128-141). 6th International Plant Breeding Conference, Ismailia, Egypt.

Esmail, R. M., Eldessouky, E. I., Mahfouze, S. A., \& EL-Demardash, I. S. (2016). Evaluation of new bread wheat lines (Triticum aestivum L) under normal and water stress conditions. International Journal of Chemtech Research, 5(9), 89-99.

FAO (Food and Agriculture Organization of the United Nations). (2019). FAOSTAT. FAO, Rome. Retrieved from http://faostat.fao.org

Francisco, R., Gregorio, A., Angela, P., Juan, B., \& José, C. (2018). AGD-R (Analysis of Genetic Designs in R) (Version 5.0). International Maize and Wheat Improvement Center (CIMMYT).

Gámez, A. L., Vicente, R., Sanchez-Bragado, R., Jauregui, I., Morcuende, R., Goicoechea, N., \& Aranjuelo, I. (2020). Differential Flag Leaf and Ear Photosynthetic Performance Under Elevated $\left(\mathrm{CO}_{2}\right)$ Conditions During Grain Filling Period in Durum Wheat. Frontiers in Science, 11, 1-12. https://oi.org/10.3389/ fpls.2020.587958

Gautam, A., Sai Prasad, S. V., Ambati, D., Agarwal, D., \& Jajoo, A. (2016). Performance of durum wheat genotypes under drought and terminal heat stress conditions in changing climatic conditions. RRJBS, 5(3), 25-31.

Golparvar, R. A. (2013). Genetic control and combining ability of flag leaf area and relative water content traits of bread wheat cultivars under drought stress condition. Genetika, 45(2), 351-360 .https://doi.org/10.2298/ GENSR1302351G

Gomaa, M. A., El-Banna, M. N. M., Gadalla, A. M., Kandil, E. E., \& Ibrahim, A. R. H. (2014). Heterosis, combining ability and drought susceptibility index in some crosses of bread wheat (Triticum aestivum L.) under water stress conditions. Middle East J. Agric. Res., 3(2), 338-345.

Gomez, K. A., \& Gomez, A. A. (1984). Statistical Proceduress for Agriculture Researach. John Wiely and Sons, Inc. New York. 
Griffing, B. (1956). Concept of general and specific combining ability in relation to diallel crossing system. Aust. J. Biol. Sci., 9, 463-493. https://doi.org/10.1071/BI9560463

Hasheminasab, H., Assad, M. T., Ali, A. A., \&. Sahhafi, S. R. (2012). Evaluation of some physiological traits associated with improved drought tolerance in Iranian wheat. Annals of Biological Research, 3(4), 1719-1725. https://doi.org/10.5539/jas.v4n8p20

Jatoi, W. A., Baloch, M. J., Khan, N. U., Munir, M., Khakwani, A. A., Vessar, N. F., ... Gul, S. (2014). Heterosis for yield and physiological traits in wheat under water stress conditions. The Journal of Animal \& Plant Sciences, 24(1), 252-261.

Khaliq, I., Parveen, N., \& Chowdhry, M. A. (2004) Correlation and path co-efficient analyses in bread wheat. Int. J. Agr. Biol., 6, 633-635.

Khan, S. A., \& Hassan, G. (2017). Heritability and correlation studies of field and yield related traits in bread wheat. Sarhad Journal of Agriculture, 33(1), 103-107. https://doi.org/10.17582/journal.sja/2017.33.1. 103.107

Khatab, I. A., Farid, M. A., \& Abd El-Lateef, M. A. (2016). Physiological and molecular effects of drought stress on bread wheat (Triticum aestivum L.) genotypes. 3rd International Conference on Biotechnology Applications in Agriculture (ICBAA), Benha University, Moshtohor and Sharm El-Sheikh, Egypt.

Kumar, D., Kerkhi, S. A., Singh, G., \& Singh, J. B. (2015). Estimates of genetic parameters for grain yield, agro-morphological traits and quality attributes in bread wheat (Triticum aestivum L.). Indian Journal of Agricultural Sciences, 85(5), 622-7.

Mandal, A. B., \& Madhuri, G. (2016). Combining ability analysis for morphological and yield traits in wheat (Triticum aestivum). J. Plant Sci. Res., 3(2), 157.

Masood, M. S., Javaid, A., Rabbani, M. A., \& Anwar, R. (2005). Phenotypic diversity and trait association in bread wheat landraces from Baluchistan, Pakistan. Pak. J., 4(37), 949-957 .

Mohamed, N. E. M., \& Morsy, A. S. M. (2013). Trials for alleviating the adverse effects of soil salinity on seed germination, growth and nutritional status of wheat seedlings (Triticum aestivum L.). Stem Cell, 4(2), 9-14.

Mohammadi, M., Sharifi, P., Karimizadeh, R., \& Shefazadeh, M. K. (2012). Relationships between grain yield and yield components in bread wheat under different water availability (dry land and supplemental irrigation conditions). Not Bot Horti Agrobo, 40(1), 195-200. https://doi.org/10.15835/nbha4017350

Moharam, M. H. A., Mohamed, M. D. A., \& Mohamed, N. E. (2017). Piriformospora indica, a plant-root-colonising fungus enhances growth and tolerance of wheat to seedlings damping-off caused by Fusarium oxysporum. Archives of Phytopathology and Plant Protection, 50(9-10), 473-490. https://doi.org/ 10.1080/03235408.2017.1328843

Monyo, J. H., \& Whittington, W. J. (1973). Genotypic differences in flag leaf area and their contribution to grain yield in wheat. Euphytica, 22, 600-606. https://doi.org/10.1007/BF00036661

Said, A. A. (2014). Generation mean analysis in wheat (Triticum aestivum L.) under drought stress conditions. Annals of Agricultural Science, 59(2), 177-184. https://doi.org/10.1016/j.aoas.2014.11.003

Saleem, S., Kashif, M., Hussain, M., Khan, A., \& Saleem, M. F. (2016). Genetic behavior of morpho-physiological traits and their role for breeding drought tolerant wheat. Pak. J. Bot., 48(3), 925-933.

Samah, E.A. (2019). Diallel analysis for drought stress related traits in bread wheat (Triticum aestivum L.) (M.Sc Thesis, Dep., Agronomy, Faculty of Agriculture, Sohag University, Egypt).

SAS Institute. (2008). The SAS system for Windows, Release 9.2. SAS Institute, Cary, N.C., USA.

Sharma, V., \& Uddin, K. (2020) Heterosis for yield and physio-biochemical traits In bread wheat (Triticum aestivum L.) Under different Environmental conditions. Bangladesh J. Bot., 49(3), 515-520. https://doi.org/ 10.3329/bjb.v49i3.49618

Sharma, V., Dodiya, N. S., Dubey, R. B., Khandagale, S. G., \& Shekhawat, N. (2018). Estimation of heterosis for yield and some yield components in bread wheat. J. Pharmacognosy and Phytochem., 7, 1742-1745.

Snedecor, G. W., \& Cochran, W. G. (1989). Statistical Method (8th ed.). Iowa State Univ. Press, Ames, USA; Institute, Cary, N.C. USA. 
Tambussi, E. A., Bort, J., Guiamet, J. J., Nogués, S., \& Araus, J. L. (2007). The photosynthetic role of ears in C3 cereals: metabolism, water use efficiency and contribution to grain yield. Crit. Rev. Plant Sci., 26, 1-16. https://doi.org/10.1080/07352680601147901

Vicente, R., Vergara-Díaz, O., Medina, S., Chairi, F., Kefauver, S. C., Bort, J., ... Araus, J. L. (2018). Durum wheat ears perform better than the flag leaves under water stress: gene expression and physiological evidence. Environ. Exp. Bot., 153, 271-285. https://doi.org/10.1016/j.envexpbot.2018.06.004

Wanga, X., Cai, J., Jianga, D., Liub, F., Dai, T., \& Cao, W. (2011). Pre-anthesis high-temperature acclimation alleviates damage to the flag leaf caused by post-anthesis heat stress in wheat. Journal of Plant Physiology, 168, 585-593. https://doi.org/10.1016/j.jplph.2010.09.016

Zareian, A., \& Tabatabaei, S. A. (2014). Field performance of three wheat cultivars under drought stress and potassium foliar application treatments. Electronic Journal of Biolog, 10(3), 52-58.

\section{Copyrights}

Copyright for this article is retained by the author(s), with first publication rights granted to the journal.

This is an open-access article distributed under the terms and conditions of the Creative Commons Attribution license (http://creativecommons.org/licenses/by/4.0/). 